\title{
Characterization of Membrane-associated Progesterone Receptor Component-2 (MAPRC2) From Trichinella spiralis and Its Interaction With Progesterone and Mifepristone
}

\section{Muhammad Tahir Aleem}

Nanjing Agricultural University

Shi Jiawen

Nanjing Agricultural University

Zheng Qing Yu

Nanjing Agricultural University

Zhao hai Wen

Nanjing Agricultural University

Zhang Yang

Nanjing Agricultural University

Liang Meng

Nanjing Agricultural University

Shakeel Ahmed Lakho

Nanjing Agricultural University

Muhammad Haseeb

Nanjing Agricultural University

\section{Haider Ali}

Nanjing Agricultural University

Muhammad Waqas Hassan

Nanjing Agricultural University

Xiao Kai Song

Nanjing Agricultural University

Li Xiangrui

Nanjing Agricultural University

Li Xin Xu

Nanjing Agricultural University

Ruo Feng Yan ( $\nabla$ yanruofeng@njau.edu.cn )

MOE Joint International Research Laboratory of Animal Health and Food safety https://orcid.org/00000001-8899-2777 


\section{Research Article}

Keywords: Trichinella spiralis, Progesterone receptor, MAPRC2, Pregnancy, Progesterone, Mifepristone, Hormones

Posted Date: May 4th, 2021

DOI: https://doi.org/10.21203/rs.3.rs-443382/v1

License: @ (i) This work is licensed under a Creative Commons Attribution 4.0 International License. Read Full License 


\section{Abstract}

Background: Trichinellosis is a food-borne zoonotic disease caused by nematode viz., Trichinella spiralis. Physiologically, the high progesterone (P4) doses cause new borne larvae (NBL) mortality in the parasite, while the low doses maintain pregnancy. In contrast, Mifepristone (RU486) works as an antagonist against the progesterone receptor (PR) and possesses abortifacient activities.

Methods: In the present study, T. spiralis membrane-associated progesterone receptor component-2 (Ts$M A P R C 2)$ gene was cloned and characterized by protein sequencing. Furthermore, the expression, purification, immunoblot assay, binding ability with progesterone antibody, and immunofluorescence assay were performed. A direct effect of progesterone (P4) and mifepristone (RU486) on the Ts-MAPRC2 gene was determined using in-vitro cell culture that showed different expression levels at all developmental stages [muscle larvae (ML), female adult worm (F-AL), male adult worm (M-AL) and new borne larvae (NBL)]. Subsequently, the in-vitro phenotypic effect of P4, RU486, and $r T s-M A P R C 2-A b$ on F-AL and ML stages were measured. Later on, the in-vivo phenotypic effect and relative mRNA expression of mifepristone on the F-AL stage were studied.

Results: Our results revealed that the Ts-MAPRC2 gene is critical to maintaining pregnancy in the female adult worm (F-AL) of T. spiralis. The P300 ng/mL of P4 and M100 ng/mL of RU486 showed downregulation of the Ts-MAPRC2 gene in F-AL $(P \leq 0.05)$. This plays an important role in abortion and possibly decreases the worm burden of $T$. spiralis in the host. Only P30 ng/mL showed significant upregulation in F-AL $(P \leq 0.05)$.

Conclusions: The current study provides new insights regarding the antihormone (P4 \& RU486) drug design and vaccine therapy of recombinant ( $r T s-M A P R C 2)$ protein as well as their combined effects to control $T$. spiralis infection.

\section{Background}

Trichinellosis is an important food-borne zoonotic disease caused by a nematode parasite named Trichinella spiralis (T. Spiralis), it ranked 7th among the world's most infectious parasitic diseases (1). The use of pork meat in various forms (i.e., raw, undercooked, etc.) and its by-products are the main source of infection in humans (2-4). Since China is the leading consumer of pork and its by-products (88.1 pounds per capita) where high morbidity from this disease due to the expanded dissemination of naturalized animals and human reserves increasingly becoming a serious issue (5-7). Although anti-helminthic agents are extensively practiced against Trichinellosis, their excessive use triggers the emergence of drug residues in meat, drug resistance in the parasite, and it adversely affects the environment as well. Thus, the advancement of an efficient vaccine against Trichinellosis, especially for humans and pigs, is a potential measure to prevent infection $(7,8)$. Recently, a series of proteins participated against host irruption, the viability of parasite, and therefore produced resistance as vaccine applicants. Further, their defensive effect resists $T$. Spiralis larvae to inoculate in model animals have been examined (9-12). Many types of these vaccines showed relatively positive action against $T$. Spiralis infection; yet, no such vaccine commercially 
available that provides adequate immunity against $T$. Spiralis infection (1). In recent years, the use of hormonal-based drugs is being considered a novel and effective alternative that offers appealing approaches against parasitic diseases. Progesterone (P4) is a gonadal hormone synthesized in the female ovary, male adrenal cortex, testes, and its levels are high in females, especially in the follicular phase of the menstrual cycle as compared to males (13). P4 also has immunosuppressive effects and shifts in immune response from type $1 \mathrm{~T}$ helper (Th1) to type $2 \mathrm{~T}$ helper $(\mathrm{Th} 2)$ cells $(14,15)$. Anzaldúa et al. $(16)$ studied the highest level of $\mathrm{P} 4$ that causes resistance against parasite invasion during pregnancy. Physiologically, the association between the increase in the P4 doses and induction of NBL mortality was observed in $T$. spiralis and T. zimbabwensis $(17,18)$.

On the other hand, mifepristone (RU486) works as an antagonist against the progesterone receptor (PR) and glucocorticoid receptor (GR) with abortifacient and anticancer activities (19). P4 acts by non-genomic pathways mediated with membrane-binding progesterone, including membrane progesterone receptors (mPRs), progesterone receptor membrane component-1(PGRMC-1), progesterone receptor membrane component-2 (PGRMC-2), and specified in humans $(20,21)$. PGRMC-2 is expressed in many tissues, especially expressed in the placenta with other reproductive tissues, and also non-reproductive tissues (liver and nervous tissues). Surprisingly, this receptor membrane(PGRMC-2) was also found in another organism like Caenorhabditis elegans (C. elegans), illustrated to express an analogous protein (vem-1) in mammals (22). In the case of helminths, a few studies present research related to PGRMC receptors (23). Prior studies observed different proteins related to sex hormone receptors comprising PGRMC, progestininduced protein, p48 progesterone-receptor-associated protein, small androgen receptor-interacting proteins that were found in Schistosoma japonicum $(24,25)$. Likewise, mifepristone (RU486), was one of the first medications approved for surgical abortion, it is often used to terminate an early or mid-term pregnancy (26). Hence, progesterone receptor (PR) and binding type of P4 molecules (agonist) and RU486 (antagonist) might be helpful to elaborate $T$. spiralis species regarding differentiation and reproductive development as well as creating potential pharmacological targets that might be used as a drug therapy against Trichinellosis.

The purpose of this study was to clone and characterize the $T$. spiralis membrane-associated progesterone receptor component-2 (Ts-MAPRC2) gene. Subsequently, we studied the protein sequencing, expression, purification, immunoblot assay, immunofluorescence assay (IFA), and binding ability with Progesterone (P4). Further, this study used an in-vitro cell culture technique to find out the direct effect of progesterone (P4) and mifepristone (RU486) on Ts-MAPRC2, which showed different expression levels of Ts-MAPRC2 gene at all developmental stages [female adult worm (F-AL), male adult worm (M-AL), muscle larvae (ML), new borne larvae (NBL)] of $T$. spiralis. Similarly, the in-vitro phenotypic effect of P4, RU486, and $r T s$ MAPRC2-Ab (rat- anti-sera- against $r T s-M A P R C 2)$ on F-AL and ML stages were observed. Additionally, the in-vivo phenotypic effect and relative mRNA expression of mifepristone (RU486) on the F-AL stage were studied. This approach will help to design new antihormone (P4 \& RU486) drug and vaccine therapy of recombinant ( $r$ Ts-MAPRC2) protein with their combined effect to control Trichinellosis.

\section{Methods}




\section{Animals and Parasites Preservation}

BALB/c mice (body-weight 18-20g) and SD (Sprague-Dawley) rats (body-weight 220-250g) were bought from Qinglongshan, Animal breeding farm, Nanjing, Jiangsu P.R. China (certified: SCXK 2008-0004); maintained under supervised condition by Animal House of Nanjing Agricultural University. T. spiralis (ISS534) utilized in this experiment was isolated from a pig in Nanyang, Henan Province, China, and were preserved by serial passage in BALB/c mice after every 6-8 months. T. spiralis muscle larvae (ML) were restored from BALB/c mice by 40 dpi (days post-infection) with standardized $\mathrm{HCl}$-pepsin digestion technique (27). Adult worms ( $A L$ ) were retrieved from intestine at $6 \mathrm{dpi}$, and new borne larvae (NBL) were recovered from a female adult at $6 \mathrm{dpi}$ from the RPMI- 1640 culture media at $37^{\circ} \mathrm{C}$ for $24 \mathrm{~h}$ as previously described by $(28,29)$. The parasite collected at different development phases were homogenized and chilled in liquid nitrogen.

\section{Sequence Analysis of Ts-MAPRC2}

The whole-genome coding sequence of the Trichinella spiralis (Ts) membrane-associated progesterone receptor component-2 (Ts-MAPRC2) gene (GeneBank Accession No. XM_003375886.1) was primarily obtained from the online GeneBank, The National Center for Biotechnology Information (http://www.ncbi.nlm.nih.gov/). Sequence properties of Ts-MAPRC2 were studied from the Expasy website (http:// www.expasy.org/). The Phylogenetic analysis of the MAPRC2 (Trichinella spiralis) protein sequence was carried out with identical genes from the other strains using the Clustal Omega (https://www.ebi.ac.uk/Tools/msa/clustalo/). Prediction of transmembrane in protein and N-terminal Signal peptide prediction were confirmed by online tools TMHMM (http://www.cbs.dtu.dk/services/TMHMM/) and SignalP-5.0 Server (http://www.cbs.dtu.dk/services/SignalP/).

\section{Cloning of Ts-MAPRC2}

The full-length sequence of Ts-MAPRC2 comprises 234 amino acids (aa) (705 bp). Fragment size of 97234aa (225-705bp) from the Ts-MAPRC2 having conserved domain (104-173aa) was expressed in the current study. The Ts-MAPRC2 gene of $T$. spiralis was amplified using RT-PCR analysis. Specific sense (5'GAATTC AATAGATTTCGTATAAAATGGACATCT-3') and anti-sense (5'- AAGCTT TCACTGATCATCAACATCACAATCAGAG - 3) primers were used with restriction enzymes EcoR \and Hind III. The amplified PCR materials were electrophoresed and cleansed through Gel-Extraction Kit (Omega, USA) and eventually ligated into cloning vector pMD19-T (TaKaRa, China). The recombinant (pMD19-T/ $T s-M A P R C 2)$ plasmid was further processed into E. coli (DH5a) strain (Invitrogen, China) and cultivated in LB (Luria Bertani) medium with ampicillin $(100 \mu \mathrm{g} / \mathrm{mL})$. Positive bacterial (pMD19-T/ Ts-MAPRC2) clones were assured by digestion of restriction enzymes and confirmed through sequencing (Invitrogen, China).

\section{Development of recombinant Ts-MAPRC2 (rTs-MAPRC2)}

The restriction digestion of the plasmid (pMD19-T/ Ts-MAPRC2) was carried out by using the enzymes viz., $E C O R \rrbracket$, and Hind III were cloned into the prokaryotic expression vector pET-32a (+) (Novagen, USA). 
Recombinant plasmid (pET32a (+)/Ts-MAPRC2) was then processed into BL21 (DE3) and induced protein expression by $1 \mathrm{mM}$ IPTG (Isopropyl- $\beta$-D-thiogalactopyranoside) (Sigma-Aldrich). Further, cells were harvested and lysed by lysozyme $(10 \mu \mathrm{g} / \mathrm{mL})$ (Sigma-Aldrich, USA), pursued by sonication. The sonicated outputs were subsequently confirmed on the SDS-PAGE (12\% w/v). Recombinant Ts-MAPRC2 (rTs$M A P R C 2)$ protein was purified by the His-TrapTM FF column following the manufacturer's instructions (GE Healthcare, USA), and protein concentration was calculated by Pierce-TM BCA-Protein Assay Kit (Thermo Scientific, USA). Also, empty pET32a (histidine-tagged) protein was purified and expressed using the same procedure mentioned above for Ts-MAPRC2, and utilized vector-protein as a negative control. Pictures of the SDS-PAGE carrying the rTs-MAPRC2 purified protein were taken. The stock of $\mathrm{r}$ Ts-MAPRC2 protein was prepared and preserved at $-80^{\circ} \mathrm{C}$ until the next experiments.

\section{Generation of the rat-polyclonal antibody of rTs-MAPRC2}

For anti-sera preparation, SD-rats $(\mathrm{n}=3)$ were immunized subcutaneously with $r T s-M A P R C 2$ protein (300 $\mu \mathrm{g})$ combined with Freund's complete adjuvant (Sigma-Aldrich, Darmstadt, Germany) equally. After two weeks, the second dose of $200 \mu \mathrm{g} r \mathrm{r}-M A P R C 2$ protein was inoculated with Freund's Incomplete Adjuvant (Sigma-Aldrich). Again, we repeated the same two booster doses at an interval of one week. After one week of the last dose, serum samples were collected and stored at $-80^{\circ} \mathrm{C}$ for further experiments. Serum collected from non-treated rats $(n=3)$ was used as a negative control.

\section{Immuno-blot assay of rTs-MAPRC2}

Separation of $r T s-M A P R C 2$ protein carried by SDS-PAGE (12\%), and were transferred to nitrocellulose membrane (Millipore, USA). Afterward, the membrane was blocked with skim milk ( $5 \% \mathrm{w} / \mathrm{v}$ ) powder in TBST $\left(0.5 \%\right.$ Tween- 20 in TBS) at $37^{\circ} \mathrm{Cfor} 2 \mathrm{~h}$. Then washed three times with TBST, and membrane again incubated with primary antibody (rat- anti-sera- against $r T s-M A P R C 2)$ at $37^{\circ} \mathrm{C}$ for $1 \mathrm{~h}$ (1:300 dilution). For negative control, we used the normal rat serum. Following this, the strips were washed three times and again incubated with secondary antibody conjugated-Horseradish peroxidase (HRP) goat-anti-rat IgG (1:3000 dilutions) (Sigma, St. Louis, MO, USA) for $2 \mathrm{~h}$ at $37^{\circ} \mathrm{C}$. In the end, the immune-reaction were appeared within 3-5 min, as per the manufacturer's directions of the DAB-HRP color development kit (Beyotime, China).

\section{Determine binding ability of rTs-MAPRC2 protein with progesterone}

In order to determine the binding ability of $r T s-M A P R C 2$ protein with progesterone, we used the progesterone antibody (PROG-Ab) kit (Sandwich ELISA kit, FY95030-B, Feiya-Biotechnology, China), the pET-32a and PBS (phosphate buffer saline) were used as a control for the relative comparison. Initially, a standard curve was prepared using different concentrations $(\mathrm{ng} / \mathrm{mL})$ of the standard sample. According to kit instructions, $50 \mu \mathrm{l}$ of the standard sample was added into three wells. Sample diluent ( $40 \mu \mathrm{l})$ was combined with $r T s-M A P R C 2$ protein $(10 \mu \mathrm{l})$ and pET-32a $(10 \mu \mathrm{l})$ protein and incubated at $37^{\circ} \mathrm{C}$ for $30 \mathrm{~min}$. After this, it was washed with the diluted washing solution (20x) 5 times for 30 sec each. Then $50 \mu \mathrm{HRP}-$ Conjugate solution was poured in each well then incubated again at $37^{\circ} \mathrm{C}$ for $30 \mathrm{~min}$. Again, it was washed 
with the diluted washing solution (20x) 5 times for $30 \mathrm{sec}$. Afterward, the $50 \mu \mathrm{l}$ Chromogen-A and Chromogen-B were added and incubated for $10 \mathrm{~min}$ at $37^{\circ} \mathrm{C}$. Finally, $50 \mu \mathrm{l}$ of a stop solution was added, and the color change from blue to yellow was observed. The optimum density (OD) values were measured at $450 \mathrm{~nm}$ with a plate reader and compared (Thermo Fisher, Life Technologies).

\section{Immunofluorescent assay of rTS-MAPRC2 at the different developmental stage}

The cross-section of $T$. spiralis samples at different developmental stages, i.e., ML, F-AL, M-AL, \& NBL were fixed in $4 \%$ formaldehyde- $0.2 \%$ glutaraldehyde with PBS for $45 \mathrm{~min}$, and liquid nitrogen was used as a frozen snap. With the use of a cryotome (CM1950-Frankfurt, Germany), worms were cut into cross-section pieces ( $10 \mu \mathrm{m}$ thick) and cleansed by PBS. First, the $5 \%$ BSA (Bovine serum albumin) was treated with slides to block non-specific binding and continued by incubation with primary antibody (rat- anti-seraagainst $r T s-M A P R C 2)$ as well as normal rat serum (control group) at $37^{\circ} \mathrm{C}$ for $2 \mathrm{~h}$ (1:300 dilution). Then both group slides were washed with PBS then incubated with Cy3-goat labeled anti-rat as a secondary antibody (Beyotime-Shanghai, China) for $1 \mathrm{~h}$ at $37^{\circ} \mathrm{C}$. Thereafter, the DAPI (diamidino-2-phenylindole) (Sigma, USA) stain was used for staining the nuclei of the worm cells for 5 min under darkness. Lastly, a laser confocal microscope (PerkinElmer, USA) was used to observed worm cross-section cells.

\section{Relative mRNA expression of Ts-MAPRC2 gene at different stages incubated with progesterone (P4) and mifepristone (RU486) by in vitro}

The powder form of progesterone (P4) and mifepristone (RU486) were purchased from Sigma (SigmaAldrich, USA), and dissolved in absolute ethanol to prepare the desired stock solution following company instruction. Furthermore, the stock solution was sterilized by using the filtration process with a $0.2 \mathrm{~mm}$ Millipore filter. The high levels of progesterone range were $100-200 \mathrm{ng} / \mathrm{mL}$ in rats, $81.9 \mathrm{ng} / \mathrm{mL}$ in mice, $25-30 \mathrm{ng} / \mathrm{mL}$ in pigs, and $25 \mathrm{ng} / \mathrm{mL}$ in pregnant women were determined (30-33). So, five different concentration of agonist progesterone (P300 ng/mL, P100 ng/mL, P30 ng/mL, P10 ng/mL, and P3 ng/mL) and also three concentrations of antagonist mifepristone (M300 ng/mL, $M 100 \mathrm{ng} / \mathrm{mL}$, and $\mathrm{M} 30 \mathrm{ng} / \mathrm{mL}$ ) were prepared. Also, control (only RPMI), and control vehicle ethanol (EtOH-RPMI)(0.125\%) were prepared described by (34). All the stages of the parasites viz., F-AL, M-AL, ML, and NBL were collected as described previously by $(28,29)$. The 2000 worms/well at all above parasite stages $(M L, A L, N B L)$ were cultured in 6well plates, and a 6-well precondition was used. The cultured medium consists of RPMI-1640, $10 \%$ heatinactivated FBS (Fetal bovine serum), and $2 \%$ antibiotics ( $100 \mathrm{U} / \mathrm{mL}$ penicillin; $100 \mathrm{mg} / \mathrm{mL}$ streptomycin) (Gibco, Paisley, UK), and incubated at the $37^{\circ} \mathrm{C}$ and $5 \%$ of $\mathrm{CO}_{2}$ for $48 \mathrm{~h}$, and the medium was changed after $24 \mathrm{~h}$ for all treatments. The female (F-AL) and male (M-AL) adult worms were separated under light microscopy using Axiovert Zeiss Microscope (25x Neo Plan objectives). Gene (Ts-MAPRC2) expression of all treated groups at various developmental stages was measured by relative quantitative PCR (qRT-PCR) as previously described by (35). Briefly, the Trizol technique was used for RNA extraction from treated groups at all stages of worms using a prime script RT reagent kit (Takara, CA, USA). The isolated RNA from each group at all parasite stages were reverse transcribed by using HiScript II Q RT SuperMix (Vazyme, Nanjing, China) kit using manufacturer instructions. The Ts-MAPRC2 gene-specific primers were used as follows: forward (5'-ACGATGTGACCCGAAAGAGA-3') and reverse (5'-CATGCATAGCCCATTCACGT-3'). 
Quantitative amplifications were performed by BI 7500 Fast Real-time PCR System (Applied Biosystem, USA) with the use of Cham-QTM SYBR qRT-PCR master mix-Kit (Vazyme, Nanjing, China). GenBank Accession No. AF452239 GADPH (Glyceraldehyde-3-phosphate dehydrogenase) of Trichinella was used as an internal control. The primer designed for GADPH were followed as forward (5'-

GTCGTGGCTGTGAATGATC-3') and reverse (5'-GCTGCCCCACTTAATTGCTT-3'), and data were computed using the comparative $\mathrm{Ct}(2-\Delta \Delta \mathrm{Ct})$ technique (35).

\section{In-Vitro phenotypic effect of P4, RU486, and rTs-MAPRC2-Ab on F-AL and ML stages}

In this experiment, the selected concentration of progesterone $(P 30 \mathrm{ng} / \mathrm{mL})$, mifepristone $(\mathrm{M} 100 \mathrm{ng} / \mathrm{mL})$, and $r T s-M A P R C 2-A b$ (rat- anti-sera- against $r T s-M A P R C 2$ ) ratio (1:300 dilution) were used at F-AL and ML stages with both controls (only RPMI and EtOH-RPMI) collected as described above, and the previously described procedures were followed according to $(28,29)$. The 2000 worms/well of both stages (F-AL, ML) were cultured in a 6-well plate, and a 6-well precondition was used. The cultured medium consists of RPMI1640, 10\% heat-inactivated FBS (Fetal bovine serum), and $2 \%$ antibiotics $(100 \mathrm{U} / \mathrm{mL}$ penicillin; $100 \mathrm{mg} / \mathrm{mL}$ streptomycin) (Gibco, Paisley, UK), and incubated at $37^{\circ} \mathrm{C}$ and $5 \% \mathrm{CO}_{2}$ for $48 \mathrm{~h}$ with medium changed after $24 \mathrm{~h}$ for all treatments. The female (F-AL) and male (M-AL) adult worms were separated under light microscopy using Axiovert Zeiss Microscope (25x Neo Plan objectives) and observed the phenotypic appearance at both stages (F-AL and ML) by using an inverted bright field microscope (Olympus, Shibuya, Japan). In the F-AL stage, the pregnancy maintenance or aborted to new borne larvae (NBL) were observed. While at the ML stage ecdysis (molting process) and motility of parasites were noted.

\section{The phenotypic effect and relative mRNA expression of mifepristone on F-AL stage by In-Vivo}

To determine the phenotypic effect of mifepristone on F-AL (female adult worm) of Trichinella spiralis, a total of 12 BALB/c mice were divided into three groups (i) mifepristone (M100 ng/mL) administration, (ii) adjuvant group EtOH (Olive oil-ethanol 3:1), and (iii) control group. Mifepristone (M100 ng/mL) powder from Sigma (Sigma-Aldrich, USA) was dissolved in a mixture of Olive oil-ethanol (EtOH) and injected subcutaneously (SC) into BALB/c mice every $24 \mathrm{~h}$ till retrieved AL (Adult worms) from the intestine at $6 \mathrm{dpi}$ (days post-infection) with $0.1 \mathrm{~mL}$ of the suspension comprising boost dose of steroid according to the protocol of González et al. (1997). In the adjuvant group EtOH (Olive oil-ethanol), BALB/c mice were administrated only adjuvant EtOH with the same protocol, and the control group was kept without any drug therapy. On day six of mifepristone $(\mathrm{M} 100 \mathrm{ng} / \mathrm{mL})$ treatment, all groups of mice have orally injected 500 T.spiralis muscle larvae (ML) with the help of gastric cannula (27). Adult worms (AL) were collected from the intestine at $6 \mathrm{dpi}$ (days post-infection) and adult worms (F-AL, M-AL) were separated using Axiovert Zeiss Microscope (25x Neo Plan objectives) and observed the phenotypic appearance, especially pregnancy, occurred or not using an inverted bright field microscope (Olympus, Shibuya, Japan). The gene (Ts-MAPRC2) expression of all the three groups at the F-AL ( female adult worm) developmental stage was also measured by relative quantitative PCR (qPCR) as described above and previously by (35).

\section{Statistical analysis}


The data were analyzed by one-way analysis of variance (ANOVA) followed by Tukey's and LSD (Least significant difference) using analytical statistics software (Statistix 8.1, USA, 2003). The qRT-PCR data

were normalized using $2^{\wedge-\Delta \Delta C t}$ in Microsoft Excel 2010 (Redmond, Washington, USA). Origin software (Origin Pro 2021) was used to perform figures (Origin Lab Corporation, Northampton, MA, USA). Statistical data were presented as mean $\pm \operatorname{SD}(n=3) . P \leq 0.05, P \leq 0.01$ were considered significant.

\section{Results}

\section{Sequence Analysis of Ts-MAPRC2}

The full-length gene sequence (Gene Bank Accession No. XM_003375886.1) of 705bp was predicted to encode protein consisting of 1-234aa, as well as possess the conserved domain of 104-173aa (Fig. S1). Fragment size of $480 \mathrm{bp}$ (between 225-705 bp) of the Ts-MAPRC2 gene were used for cloning that encodes the protein of 137aa (97-234aa) possessing the conserved domain of 6-75aa submitted online in NCBI (http://www.ncbi.nlm.nih.gov/) and issued a specific accession number (MT093680). Bioinformatics online tools TMHMM revealed that there were no transmembrane (Fig. S2A) and Signal peptide (Fig. S2B) found in Ts-MAPRC2 (MT093680). Percent matrix index (Fig. S2C) showed more similarity of the Ts$M A P R C 2$ with other trichinella species strains. Phylogenetic tree and multiple sequence alignment of $T s-$ $M A P R C 2$ by using the Clustal Omega with other trichinella species are presented in Fig. 1.

\section{Cloning of Ts-MAPRC2}

The amplified PCR product of the Ts-MAPRC2 gene (480bp) was procured successfully from cDNA of $T$. spiralis (Fig. 2A) by using the pair of primers, and cloned into pMD-19T (cloned vector). Then transformed into pET-32a (expression vector) (Fig. 2B), and confirmed by restriction enzymes digestion using the $E c o R \otimes$ and Hind III.

\section{Expression, purification, and Immunoblot of rTs-MAPRC2}

Cloned Ts-MAPRC2 gene (480bp) sequences were translated into 137aa, and molecular weight was estimated to $17.6 \approx 18 \mathrm{kDa}$. The rTs-MAPRC2 protein was expressed on SDS-PAGE (12\%) with IPTG and observed high expression after five induction hours (Fig. 3A). After purification, the molecular weight was showed around 38kDa (Fig. 3B, Lane 1) along with $20 \mathrm{kDa}$ mass of (poly his-tag pET-32a) expression vector (Fig. 3B, Lane 2). Immuno-blot assay revealed that $r T s-M A P R C 2$ could be recognized by polyclonal antibodies produced in rat serum against the rTs-MAPRC2 protein (Fig. 3C, Lane 1), and compared with normal rat serum (Fig. 3C, Lane 2). The above result showed that $r T s-M A P R C 2$ possess antigenicity, and easily recognized by the host immune system.

\section{Binding ability of rTs-MAPRC2 protein by Sandwich ELISA}

The binding capacity of $r T s-M A P R C 2$ protein with progesterone antibody (PROG-Ab) was compared with pET-32a and PBS as control. Our results revealed that there are highly significant differences $(P<0.01)$ 
between rTs-MAPRC2 protein and both controls (pET-32a and PBS) (Fig. 4) compared to the standard. But no significant difference was observed between pET-32a and PBS.

\section{Immuno-fluorescent assay (IFA) of Ts-MAPRC2 gene at various developmental stages}

IFA was performed to determine the presence of the Ts-MAPRC2 gene at different developmental stages using anti- rTs-MAPRC2 rat serum, Cy3-conjugated secondary antibody, and DAPI (nuclei dye). The crosssection cells of all developmental stages [ML, F-AL, M-AL, and NBL] of T. spiralis were studied. As shown in Fig. 5, Cy3-labeled Ts-MAPRC2 gene, DAPI-labeled nuclei displayed red and blue fluorescence for all stages cross-section cells (ML, F-AL, M-AL, and NBL) respectively. ML and F-AL stages showed high Ts-MAPRC2 gene localization as compared to M-AL and NBL stages. Moreover, F-AL showed high immunolocalization compared to M-AL. However, no red fluorescence was observed in all stages (ML, F-AL, M-AL, and NBL) of the control groups.

\section{Relative mRNA expression of Ts-MAPRC2 at all stages by in-vitro treatment of P4 and RU486}

The transcriptional pattern of Ts-MAPRC2 gene in the parasite treated at different concentration of P4 (P300 ng/mL, P100 ng/mL, P30 ng/mL, P10 ng/mL, and P3 ng/mL) as well as mifepristone (M300 ng/mL, $\mathrm{M} 100 \mathrm{ng} / \mathrm{mL}$, and $\mathrm{M} 30 \mathrm{ng} / \mathrm{mL}$ ) as well as their multi comparison analyses was investigated to find out the up-and down-regulation at different stages (F-AL, M-AL, ML, and NBL) using qRT-PCR with the transcription of GAPDH gene as a control.

\section{Comparison between the same stage and same concentration of P4}

The results of the comparative expression of the Ts-MAPRC2 gene in the F-AL stage at different concentration of P4 (P300 ng/mL, P100 ng/mL, P30 ng/mL, P10 ng/mL, and P3 ng/mL) with control (only RPMI) and control vehicle ethanol (EtOH-RPMI) are presented in Fig. 6A. All concentrations of P4 (P300 $\mathrm{ng} / \mathrm{mL}, \mathrm{P} 100 \mathrm{ng} / \mathrm{mL}, \mathrm{P} 30 \mathrm{ng} / \mathrm{mL}, \mathrm{P} 10 \mathrm{ng} / \mathrm{mL}$, and P3 $\mathrm{ng} / \mathrm{mL}$ ) showed up-regulation of the Ts-MAPRC2 gene as compared to control (only RPMI) and control vehicle ethanol (EtOH-RPMI); in contrast, the P30 showed high up-regulation expression of the Ts-MAPRC2 gene compared to all other concentrations with their both controls (only RPMI and EtOH-RPMI) $(P \leq 0.05)$. Figure 6B showed the comparative expression of Ts-MAPRC2 gene in the M-AL stage of different concentration of P4 (P300 ng/mL, P100 ng/mL, P30 $\mathrm{ng} / \mathrm{mL}$, and $\mathrm{P} 10 \mathrm{ng} / \mathrm{mL}, \mathrm{P} 3 \mathrm{ng} / \mathrm{mL}$ ) with control (only RPMI) and control vehicle ethanol (EtOH-RPMI). All concentrations of P4 (P300 ng/mL, P100 ng/mL, P30 ng/mL, P10 ng/mL, and P3 ng/mL) showed upregulation of the Ts-MAPRC2 gene relative to control (only RPMI) and control vehicle ethanol (EtOH-RPMI), but expression decreased in descending order from high concentration (P300 ng/mL) to low concentration (P3 ng/mL) compared with both controls (only RPMI and EtOH-RPMI) $(P \leq 0.05)$. comparative expression of the Ts-MAPRC2 gene in the ML stage at different concentration of P4 (P300 ng/mL, P100 ng/mL, P30 $\mathrm{ng} / \mathrm{mL}, \mathrm{P} 10 \mathrm{ng} / \mathrm{mL}$, and $\mathrm{P} 3 \mathrm{ng} / \mathrm{mL}$ ) with control (only RPMI) and control vehicle ethanol (EtOH-RPMI) are presented in the Fig. $6 \mathrm{C}$. In the $\mathrm{ML}$ stage, all treatment concentrations showed up-regulation of the $T s$ MAPRC2 gene, but P300 and P30 showed more upregulation compared with both controls (only RPMI and EtOH-RPMI) $(P \leq 0.01)$. Figure 7D shows the relative expression of the $T s-M A P R C 2$ gene in the NBL stage 
at different concentration of P4 (P300 ng/mL, P100 ng/mL, P30 ng/mL, P10 ng/mL, and P3 ng/mL) with control (only RPMI) and control vehicle ethanol (EtOH-RPMI). All concentrations of P4 (P300 ng/mL, P100 $\mathrm{ng} / \mathrm{mL}$, P30 ng/mL, P10 ng/mL, and P3 ng/mL) showed down-regulation compared with control (only $\mathrm{RPMI})$, but here control vehicle ethanol (EtOH-RPMI) also showed down-regulation.

\section{Comparison among the same stage and same concentration of mifepristone (RU486)}

Relative expression of the Ts-MAPRC2 gene in the F-AL stage at different concentrations of mifepristone (M300 ng/mL, M100 ng/mL, and M30 ng/mL) with control (only RPMI) and control vehicle ethanol (EtOHRPMI) are presented in Fig. 7A. All concentrations showed up-regulation of the Ts-MAPRC2 gene as compared with control (only RPMI) and control vehicle ethanol (EtOH-RPMI), but M100 (ng/mL) showed high up-regulation expression of the Ts-MAPRC2 gene compared to all other treatment concentrations with their both controls (only RPMI and EtOH-RPMI) $(P \leq 0.05)$. Figure 7B shows the comparative expression of the Ts-MAPRC2 gene in the M-AL stage at different concentrations of mifepristone (M300 ng/mL, M100 $\mathrm{ng} / \mathrm{mL}$, and $\mathrm{M} 30 \mathrm{ng} / \mathrm{mL}$ ) with control (only RPMI) and control vehicle ethanol (EtOH-RPMI). Here only M100 (ng/mL) showed up-regulation of the Ts-MAPRC2 gene as compared with control (only RPMI) and control vehicle ethanol (EtOH-RPMI); however, the M300 (ng/mL) showed expression same as control vehicle ethanol (EtOH-RPMI), and the M30 ( $\mathrm{ng} / \mathrm{mL}$ ) showed expression same as control (only RPMI) $(P \leq$ 0.05). Figure 7C shows the comparative expression of the Ts-MAPRC2 gene in the ML stage at different concentrations of mifepristone (M300 ng/mL, M100 ng/mL, and M30 ng/mL) with control (only RPMI) and control vehicle ethanol (EtOH-RPMI). In the ML stage, M100 (ng/mL) showed up-regulation of the TsMAPRC2 gene as compared with control (only RPMI) and control vehicle ethanol (EtOH-RPMI) but M300 $(\mathrm{ng} / \mathrm{mL})$ and $\mathrm{M} 30(\mathrm{ng} / \mathrm{mL})$ showed almost the same expression compared with both controls (only RPMI and EtOH-RPMI) $(P \leq 0.05)$. Figure 8D shows the relative expression of the $T s-M A P R C 2$ gene in the NBL stage at different concentrations of mifepristone (M300 ng/mL, M100 ng/mL, and M30 ng/mL) with control (only RPMI) and control vehicle ethanol (EtOH-RPMI). In the NBL stage, the expression decreased in descending order from high concentration $(\mathrm{M} 300 \mathrm{ng} / \mathrm{mL})$ to low concentration $(\mathrm{M} 100 \mathrm{ng} / \mathrm{mL})$ compared with both controls (only RPMI and EtOH-RPMI) $(P \leq 0.05)$. But M30 $(\mathrm{ng} / \mathrm{mL})$ showed downregulation respectively $(P \leq 0.05)$.

\section{Comparison among the P4 and RU486 at F-AL stage by using P30 and M30 as controls}

Relative expression analysis of the Ts-MAPRC2 gene in the F-AL stage at different concentrations of P4 (P300 ng/mL, P100 ng/mL, P30 ng/mL, P10 ng/mL, and P3 ng/mL) with M30 ng/mL as control are presented in Fig. 8A. P100 ng/mL, P30 ng/mL, and P10 ng/mL showed up-regulation of the Ts-MAPRC2 gene while $\mathrm{P} 300 \mathrm{ng} / \mathrm{mL}$, and $\mathrm{P} 3 \mathrm{ng} / \mathrm{mL}$ showed down-regulation as compared with $\mathrm{M} 30 \mathrm{ng} / \mathrm{mL}$ as control. Figure 8B shows the comparison expression of the Ts-MAPRC2 gene in the F-AL (Female adult worm) stage at different concentrations of mifepristone (M300 ng/mL, M100 ng/mL, and M30 ng/mL) with P30 $\mathrm{ng} / \mathrm{ml}$ as control. Here all concentrations of mifepristone $(\mathrm{M} 300 \mathrm{ng} / \mathrm{mL}, \mathrm{M} 100 \mathrm{ng} / \mathrm{mL}$, and $\mathrm{M} 30 \mathrm{ng} / \mathrm{mL}$ ) showed down-regulation compared with $\mathrm{P} 30 \mathrm{ng} / \mathrm{mL}$ as control $(\mathrm{P} \leq 0.05)$.

In-Vitro phenotypic effect of P4, RU486, and rTs-MAPRC2-Ab on F-AL and ML stages 
In-vitro phenotypic effect of P30 ng/mL, M100 ng/mL, and $r T s-M A P R C 2-A b$ on the F-AL stage revealed that observed pregnancy and abortion to produce NBL parasites (Fig. 9A). M100 (ng/mL) and rTs-MAPRC2-Ab showed more aborted NBL parasites as compared to controls (only RPMI and EtOH-RPMI), while P30 $\mathrm{ng} / \mathrm{mL}$ prolonged pregnancy period and delays abortion to NBL compared with controls (only RPMI and EtOH-RPMI). Figure 9B shows the in-vitro phenotypic effect of P30 ng/mL, M100 ng/mL, and rTs-MAPRC2$A b$ on the ML stage. Here, the M100 has more ecdysis (molting process) and motility compared with P30 $(\mathrm{ng} / \mathrm{mL}$ ) concentration, $r T s-M A P R C 2-A b$, and controls (only RPMI and EtOH-RPMI). While $r T s-M A P R C 2-A b$ also has high motility compared to P30 ng/mL, and both controls (only RPMI and EtOH-RPMI).

\section{Phenotypic effect and relative mRNA expression of mifepristone on F-AL stage by in-vivo}

In-vivo phenotypic effect of mifepristone ( $\mathrm{M} 100 \mathrm{ng} / \mathrm{mL}$ ) on F-AL (female adult worm) are presented in Fig. 10A. Comparison of the early pregnancy stage of F-AL among M100 ng/mL, EtOH (Olive oil-ethanol) with the simple control mice groups. The simple control group and $\mathrm{EtOH}$ (Olive oil-ethanol) showed normal pregnancy at $6 \mathrm{dpi}$ (days post-infection), but the F-AL of the M100 ng/mL treated mice group did not show pregnancy and only see embryos inside of the F-AL body. In-vivo study shows the relative mRNA expression of Ts-MAPRC2 at F-AL phase of T. spiralis among three groups such as $\mathrm{M} 100 \mathrm{ng} / \mathrm{mL}$, EtOH (Olive oil-ethanol) with the simple control (Fig. 10B). M100 ng/mL showed up-regulation of the Ts-MAPRC2 gene as compared with EtOH (Olive oil-ethanol) with the simple control $(P \leq 0.05)$.

\section{Discussions}

Progesterone receptor membrane component $1 \& 2$ (PGRMC-1\& PGRMC-2) belongs to the same family of MAPR (membrane-associated progesterone receptor) proteins $(36,37)$, and $P G R M C$ - 1 protein was collected first from smooth muscle of porcine with $28 \mathrm{kDa}(38,39)$. It is located in the cell membrane, endoplasmic reticulum (ER), Golgi apparatus, and consisted of a small extracellular N-terminal cytoplasmic domain and a single transmembrane domain (38-43). It also contains the sequences that bind with steroids, cytochrome-b5, and three Src similar domains that participated in ligand-dependent signal-transduction (39). PGRMC-1 expressed in many mammals (e.g., human, rodents, monkey, pigs, and cattle) reproductive tissues, and it involved in many functions i.e., steroidogenesis, cholesterol metabolism regulation, oocyte maturation, and myometrial contractility, etc. $(21,39,41,43-47)$. It is also involved in the in-vitro existence of regular and cancerous ovarian cells (48). PRMC-2 resembled PGRMC-1, but the sequence domains of these two proteins differ in the transmembrane and $\mathrm{N}$-terminal stages, showing a potential capacity of both receptors' interactions (49). PGRMC-2 also showed mRNA expression in the endometrium wall of monkeys and mice as well as in the myometrium, and endometrium of cattle's oviduct $(50,51)$. Prior studies noted that in humans women showed upregulated expression in choriodecidual tissue, especially in 35 weeks of gestation (pre-term labor) and breast adenocarcinoma (21, 41, 50-54). Likewise in helminths, a few studies reported PGRMC receptors, progestin-induced protein, p48 progesterone-receptorassociated protein, and small androgen receptor-interacting proteins that were found in S. japonicum (24, 25). The pleiotropic role of membrane-associated progesterone receptor component-2 (MAPRC2) in the 
biology of the reproductive system of $T$. spiralis suggest that it can be a new target for drug and vaccine development against Trichinellosis.

To this end, in this study we cloned, expressed the MAPRC2 gene in T. spiralis, and evaluated its expression levels with P4 (agonist) and RU486 (antagonist) hormones. Cytochrome-b5 heam/steroid binding domain present inside the Ts-MAPRC2 protein (6-75aa), and calculated with BLAST. An online bioinformatics tool (TMHMM) shows that there was not any transmembrane found in the cloned sequence (225-705bp). Notably, the percent matrix index (Fig. S2C) displayed more resemblance between the Ts-MAPRC2 and strains of other Trichinella species. Interestingly, we magnificently cloned the Ts-MAPRC2 gene, and its protein expression was confirmed via SDS-PAGE. The host immune system recognized $r T s-M A P R C 2$ protein confirmed by immunoblot assay suggested that the recombinant protein has the compatible antigenic features (Figs. $2 \& 3$ ). Moreover, a binding capacity rTs-MAPRC2 protein with a progesterone antibody (PROG-Ab) was determined by Sandwich ELISA kit (Fig. 4). This finding complements the idea that $r T s-M A P R C 2$ protein has a specific steroid-binding domain that might arbitrate the P4 effect in the reproductive process of $T$. spiralis. Likewise, $P G R M C$-2 detected mainly in reproductive parts of mammals (ovary, endometrium, placenta) associated with multiple cellular functions (differentiation, proliferation, and maturation), and also identified in epithelial cells, granulocytes, mast cells, lymphocytes, and macrophages $(36,55-57)$.

Furthermore, we examined the localization of the MAPRC2 gene in T. spiralis, immunofluorescence staining at all developmental stages that confirmed the presence of this gene throughout all the developmental stages (Fig. 5). Existing studies also performed the immunofluorescence assay to examine membranebinding progesterone protein in the T. solium cysticerci (23). likewise, many studies reported that progesterone also showed immunomodulatory response during pregnancy diverged towards the Th2 type response to activate the innate immune system $(14,58)$. Basically, in females, Th2 type immune response increased the interleukins production (IL-4,-5,-6,10) (57). Hence, in pregnant rats, resistance against $T$. spiralis has been reported due to a high progesterone level compared with non-pregnant rats. Also, in-vitro trials showed that pregnant rat sera could interrupt the death of the NBL stage of $T$. spiralis (59). From these, either stimulatory or inhibitory function of progesterone affects the immune response, based on the concentration, steroid exposure time, and type of cell studied (60). Therefore, based on the murine model, both sexes were studied against Trichinella infections, and the result showed that males mice are more susceptible to infection than female mice (61-63). Further, parasite burden interestingly increased in ovariectomized female rats compared with intact females (64). Mifepristone (RU486) worked as antagonists against glucocorticoid receptor (GR) and progesterone receptor (PR) and through anticancer and abortifacient actions (19). Mifepristone, one of the first medications approved for surgical abortion, is often used to end an early or mid-term pregnancy (26).

The in-vitro study shows relative mRNA expression of Ts-MAPRC2 gene at all stages (ML, F-AL, and M-AL, $\mathrm{NBL}$ ) treated with three different concentration of progesterone (P300 ng/mL, P100 ng/mL, P30 ng/mL, $\mathrm{P} 10 \mathrm{ng} / \mathrm{mL}$, and $\mathrm{P} 3 \mathrm{ng} / \mathrm{mL}$ ), mifepristone (M300 ng/mL, M100 ng/mL, M30 ng/mL), and their controls (ETH-RPMI \& only RPMI) $(P \leq 0.05)$. Figure 6 shows the comparison expression of the Ts-MAPRC2 gene in 
all stages (F-AL, M-AL, ML, and NBL) at a changed concentration of P4 (P300 ng/mL, P100 ng/mL, P30 $\mathrm{ng} / \mathrm{mL}, \mathrm{P} 10 \mathrm{ng} / \mathrm{mL}, \mathrm{P} 3 \mathrm{ng} / \mathrm{mL}$ ) with both controls $(\mathrm{P} \leq 0.05)$. All concentrations of $\mathrm{P} 4(\mathrm{P} 300 \mathrm{ng} / \mathrm{mL}, \mathrm{P} 100$ $\mathrm{ng} / \mathrm{mL}, \mathrm{P} 30 \mathrm{ng} / \mathrm{mL}, \mathrm{P} 10 \mathrm{ng} / \mathrm{mL}$, and P3 $\mathrm{ng} / \mathrm{mL}$ ) showed up-regulation of the Ts-MAPRC2 gene in three stages (F-AL, M-AL, and ML) but NBL showed down-regulation as compared with both controls $(P \leq 0.05)$. In the F-AL stage, P30 showed high up-regulation expression of the Ts-MAPRC2 gene compared to all other concentrations with both controls $(P \leq 0.05)$. From these results, one can argue that $P 300 \mathrm{ng} / \mathrm{mL}$ concentration of $\mathrm{P} 4$ levels up to a certain limit moves toward downregulation; this strongly emphasizes the maximum levels of progesterone range $100-200 \mathrm{ng} / \mathrm{mL}$ in rats affect the death of new borne larvae in $T$. spiralis (17).

Figure 7 shows the comparison expression of the Ts-MAPRC2 gene in all stages (F-AL, M-AL, ML, and NBL) at different doses of mifepristone (M300 ng/mL, M100 ng/mL, and M30 ng/mL) with controls (only RPMI and EtOH-RPMI). All concentrations of (M300 ng/mL, M100 ng/mL, and M30 ng/mL) showed upregulation expression in F-AL, M-AL and ML stages, but in the NBL stage only $M 300 \mathrm{ng} / \mathrm{mL}, \mathrm{M} 100 \mathrm{ng} / \mathrm{mL}$ showed up-regulation expression compared by controls $(P \leq 0.05)$. In the F-AL stage, only $\mathrm{M} 100 \mathrm{ng} / \mathrm{mL}$ showed high up-regulation expression of the Ts-MAPRC2 gene that confirms this concentration is good as antagonists against progesterone receptor (PR) as well as abortifacient activities. Further, we confirmed through a cross-comparison expression of the Ts-MAPRC2 gene among the P4 and RU486 at the F-AL stage by P30 $\mathrm{ng} / \mathrm{mL}$ and $\mathrm{M} 30 \mathrm{ng} / \mathrm{mL}$ used as controls. Figure $8 \mathrm{~A}$ compared the expression of the $T s$ MAPRC2 gene in the F-AL stage in all concentrations of P4 (P300 ng/mL, P100 ng/mL, P30 ng $/ \mathrm{mL}, P 10$ $\mathrm{ng} / \mathrm{mL}$, and P3 ng/mL) with $\mathrm{M} 30 \mathrm{ng} / \mathrm{mL}$ as control. The P100 ng/mL, P30 ng/mL, and P10 ng $/ \mathrm{mL}$ showed upregulation, while P300 ng/mL, P3ng/mL showed downregulation with $\mathrm{M} 30 \mathrm{ng} / \mathrm{mL}$ as control but noted that P30 $\mathrm{ng} / \mathrm{mL}$ still shows high up-regulation. Figure 8B compares the expression of the Ts-MAPRC2 gene in the F-AL stage at different concentrations of mifepristone (M300 ng/mL, M100 ng/mL, and M30 ng/mL) with P30 ng/mL as control. All concentration of mifepristone (M300 ng/mL, M100 ng/mL, M30 ng/mL) showed down-regulation compared to $P 30 \mathrm{ng} / \mathrm{mL}$ as control $(P \leq 0.05)$. Finally, we concluded that the progesterone (P4) upregulate the Ts-MAPRC2 gene at a low concentration of P30 ng/mL but downregulated the $T s-M A P R C 2$ gene at $\mathrm{P} 300 \mathrm{ng} / \mathrm{mL}$, in the F-AL stage compared with $\mathrm{M} 30 \mathrm{ng} / \mathrm{mL}$ positive control, this corroborated with the findings of (17) indicating more resistance against $T$. spiralis due to a high progesterone level compared with virgin rats. Also, in-vitro trials showed pregnant rat sera could interrupt newborn larvae (NBL) death of $T$. spiralis (59). Although, RU486 (antagonist) downregulated the Ts-MAPRC2 gene at all concentrations (M300 ng/mL, M100 ng/mL, and M30 ng/mL) compared with P30 $\mathrm{ng} / \mathrm{mL}$ as a positive control that claims the mifepristone (RU486) function as antagonists against progesterone receptor (PR) and abortifacient activities (19).

Based on this analysis, we subsequently examined the phenotypic appearance of pregnant F-AL among P30 $(\mathrm{ng} / \mathrm{mL}), \mathrm{M} 100(\mathrm{ng} / \mathrm{mL})$, and $r T s-M A P R C 2-A b$ with controls (only RPMI and EtOH-RPMI) by in-vitro. $\mathrm{M} 100 \mathrm{ng} / \mathrm{mL}$ and $r T s-M A P R C 2-A b$ showed more aborted NBL parasites as compared to controls while P30 $\mathrm{ng} / \mathrm{mL}$ prolong pregnancy and delays in abortion to produce NBL compared with control groups (only RPMI and EtOH-RPMI) (see Fig. 9A), these findings are in line with the findings of $(17,19)$. Further, Fig. 9B shows the comparison of the phenotypic appearance of muscle larvae $(\mathrm{ML})$ among P30 (ng/mL), M100 
$\mathrm{ng} / \mathrm{mL}$, and $r T s-M A P R C 2-A b$ with both controls (only RPMI and EtOH-RPMI) to observe ecdysis (molting process) and motility. M100 $\mathrm{ng} / \mathrm{mL}$ has more ecdysis (molting process) and motility compared with P30 $\mathrm{ng} / \mathrm{mL}$ concentration, $r T s-M A P R C 2-A b$, and controls (only RPMI and EtOH-RPMI). While $r T s-M A P R C 2-A b$ has high motility compared to $\mathrm{P} 30 \mathrm{ng} / \mathrm{mL}$ and both controls (only RPMI and EtOH-RPMI) correspondingly supported by the finding of (65). Figure 10 shows the in-vivo study of phenotypic effect and relative mRNA expression of $\mathrm{M} 100 \mathrm{ng} / \mathrm{mL}$ on the F-AL stage. The simple control group and EtOH (Olive oil-ethanol) shows normal pregnancy at $6 \mathrm{dpi}$ (days post-infection) but F-AL of M100 ng/mL treated mice grouped did not show pregnancy and only see embryos inside of the F-AL body. $M 100 \mathrm{ng} / \mathrm{mL}$ showed up-regulation of the Ts-MAPRC2 gene as compared with EtOH (Olive oil-ethanol) and the simple control (P $\leq 0.05)$ (Fig. 10B), these findings are amply supported by $(19,65)$.

\section{Conclusions}

To conclude, the M100 ng/mL were resulting in downregulation of the Ts-MAPRC2 gene, which in turn leads to abortion in vivo as well as in vitro in F-AL. However, the P30 $\mathrm{ng} / \mathrm{mL}$ restrains the pregnancy in the early stage of F-AL. P30 ng/mL showed up-regulation of the target gene and had a positive effect on the pregnancy as compared to P300 $\mathrm{ng} / \mathrm{mL}$. To the best of our knowledge, this is the first study regarding cloning, expression of the rTs-MAPRC2 gene, and its expression level with sex hormones (P4 \& RU486) at all developmental stages (ML, F-AL, and M-AL, NBL) as well as in-vitro and in-vivo phenotypic effects in FAL stage of T. spiralis. This opens a new horizon about antihormone (P4 \& RU486) drug design, and vaccine therapy of recombinant (rTs-MAPRC2) protein with their combined effect to control Trichinellosis.

\section{Abbreviations}

AL: Adult worms; NBL: new borne larvae; ML: muscle larvae; F-AL: female adult worm; M-AL: male adult worm; PR: progesterone receptor; Ts-MAPRC2: Trichinella spiralis membrane-associated progesterone receptor component-2; P4: Progesterone; RU486: Mifepristone; EtOH: Olive oil-ethanol

\section{Declarations}

\section{Acknowledgements}

We highly acknowledge the research team of the Laboratory of Parasitology and molecular Immunology, Nanjing Agricultural University, China, for their help during this study.

\section{Authors' contributions}

YRF directed the project and participated in the coordination and management of the study. MTA performed the laboratory experiments and wrote the manuscript. SJ, ZQY, ZW, ZY, LM assisted on the laboratory tests on Trichinella spiralis species. SAL, MH, MWH, analyzed the data, and HA, MWH, provided some ideas for the experimental design. LXR, SXK, and XLX provided new analytical reagents and tools. All authors read and approved the final manuscript. 


\section{Funding}

This work was supported by the Natural Science Foundation of Jiangsu Province, P. R. China (BK20141365) and a project funded by the Priority Academic Program Development of Jiangsu Higher Education Institutions (PAPD).

\section{Availability of data and materials}

All data generated or analyzed during this study are included within the article and its additional information file.

\section{Ethics approval and consent to participate}

Regarding the animals included in our research, this study followed the guidelines of the Animal Ethics Committee, Nanjing Agricultural University, China. The approval ID was SCXK 2008-0004.

\section{Consent for publication}

Written informed consent was obtained from the participants for the publication of this paper.

\section{Conflicts of Interest}

The authors declare no conflict of interest

\section{References}

1. Yang Y, Bai X, Li C, Tong M, Zhang P, Cai W, et al. Molecular characterization of fructose-1,6bisphosphate aldolase from trichinella spiralis and its potential in inducing immune protection. Frontiers in Cellular and Infection Microbiology. 2019;9(APR):1-11.

2. Cui J, Wang ZQ. An epidemiological overview of swine trichinellosis in China. Vol. 190, Veterinary Journal. W.B. Saunders; 2011. p. 323-8.

3. Darwin Murrell K, Pozio E. Worldwide occurrence and impact of human trichinellosis, 1986-2009. Emerging Infectious Diseases [Internet]. 2011 [cited 2020 Dec 14];17(12):2194-202. Available from: /pmc/articles/PMC3311199/?report=abstract

4. WHO | Multicriteria-based ranking for risk management of food-borne parasites. WHO [Internet]. 2016 [cited 2020 Dec 14]; Available from: http://www.who.int/foodsafety/publications/mra_23/en/

5. Cui J, Jiang P, Liu LN, Wang ZQ. Survey of Trichinella infections in domestic pigs from northern and eastern Henan, China. Veterinary Parasitology. 2013 May 20;194(2-4):133-5.

6. Jiang P, Zhang X, Wang LA, Han LH, Yang M, Duan JY, et al. Survey of Trichinella infection from domestic pigs in the historical endemic areas of Henan province, central China. Parasitology Research [Internet]. 2016 Dec 1 [cited 2020 Dec 14];115(12):4707-9. Available from: https://link.springer.com/article/10.1007/s00436-016-5240-x 
7. Bai X, Hu X, Liu X, Tang B, Liu M. Current Research of Trichinellosis in China. Frontiers in Microbiology [Internet]. 2017 Aug 2 [cited 2020 Dec 14];8(AUG):1472. Available from:

http://journal.frontiersin.org/article/10.3389/fmicb.2017.01472/full

8. Zhang N, Li W, Fu B. Vaccines against Trichinella spiralis: Progress, challenges and future prospects [Internet]. Vol. 65, Transboundary and Emerging Diseases. Blackwell Publishing Ltd; 2018 [cited 2020 Dec 14]. p. 1447-58. Available from: https://pubmed.ncbi.nlm.nih.gov/29873198/

9. Feng S, Wu X, Wang X, Bai X, Shi H, Tang B, et al. Vaccination of mice with an antigenic serine protease-like protein elicits a protective immune response against Trichinella spiralis infection. Journal of Parasitology. 2013 Jun;99(3):426-32.

10. Gu Y, Sun X, Li B, Huang J, Zhan B, Zhu X. Vaccination with a paramyosin-based multi-epitope vaccine elicits significant protective immunity against Trichinella spiralis infection in mice. Frontiers in Microbiology. 2017;8(AUG):1-9.

11. Song YY, Zhang Y, Yang D, Ren HN, Sun GG, Jiang P, et al. The immune protection induced by a serine protease inhibitor from the foodborne parasite trichinella spiralis. Frontiers in Microbiology [Internet]. 2018 Jul 11 [cited 2020 Dec 14];9(JUL). Available from: https://pubmed.ncbi.nlm.nih.gov/30050521/

12. Yang Z, Li W, Yang Z, Pan A, Liao W, Zhou X. A novel antigenic cathepsin B protease induces protective immunity in Trichinella-infected mice. Vaccine. 2018 Jan 4;36(2):248-55.

13. Jenkins J. Yen and Jaffe's Reproductive Endocrinology: Physiology, Pathophysiology and Clinical Management, 5th edition. The Obstetrician \& Gynaecologist [Internet]. 2006 Jul 16 [cited 2020 Dec 14];8(3):201-201. Available from: http://doi.wiley.com/10.1576/toag.8.3.201.27262

14. Piccinni MP, Giudizi MG, Biagiotti R, Beloni L, Giannarini L, Sampognaro S, et al. Progesterone favors the development of human T helper cells producing Th2-type cytokines and promotes both IL-4 production and membrane CD30 expression in established Th1 cell clones. The Journal of Immunology. 1995;155(1).

15. Miyaura H, Iwata M. Direct and Indirect Inhibition of Th1 Development by Progesterone and Glucocorticoids. The Journal of Immunology [Internet]. 2002 Feb 1 [cited 2020 Dec 14];168(3):108794. Available from:

http://www.jimmunol.org/content/168/3/1087http://www.jimmunol.org/content/168/3/1087.full\#reflist-1

16. Anzaldúa SR, Camacho-Arroyo I, Cerbón MA. Histomorphological changes in the oviduct epithelium of the rabbit during early pregnancy. Anatomia, Histologia, Embryologia [Internet]. 2002 [cited 2020 Dec 13];31(5):308-12. Available from: https://pubmed.ncbi.nlm.nih.gov/12484426/

17. Nuñez GG, Gentile T, Costantino SN, Sarchi MI, Venturiello SM. In vitro and in vivo effects of progesterone on Trichinella spiralis newborn larvae. Parasitology. 2005;131(2):255-9.

18. Hlaka L, Chitanga S, Masola B, Mukaratirwa S. Host pregnancy influences the establishment of Trichinella zimbabwensis in Balb C mice. Journal of Parasitic Diseases. 2017;41(3):799-804.

19. Chen J, Wang J, Shao J, Gao Y, Xu J, Yu S, et al. The Unique Pharmacological Characteristics of Mifepristone (RU486): From Terminating Pregnancy to Preventing Cancer Metastasis. Medicinal 
Research Reviews [Internet]. 2014 [cited 2020 Dec 13];34(5):979-1000. Available from: https://pubmed.ncbi.nlm.nih.gov/24585714/

20. Gerdes D, Wehling M, Leube B, Falkenstein E. Cloning and tissue expression of two putative steroid membrane receptors. Biological Chemistry [Internet]. 1998 Jul [cited 2020 Dec 14];379(7):907-11. Available from: https://pubmed.ncbi.nlm.nih.gov/9705155/

21. Kowalik MK, Slonina D, Rekawiecki R, Kotwica J. Expression of progesterone receptor membrane component (PGRMC) 1 and 2, serpine mrnabinding protein 1 (SERBP1) and nuclear progesterone receptor (PGR) in the bovine endometrium during the estrous cycle and the first trimester of pregnancy. Reproductive Biology [Internet]. 2013 [cited 2020 Dec 15];13(1):15-23. Available from: https://pubmed.ncbi.nlm.nih.gov/23522067/

22. Runko E, Kaprielian Z. Caenorhabditis elegans VEM-1, a novel membrane protein, regulates the guidance of ventral nerve cord-associated axons. Journal of Neuroscience. 2004;24(41):9015-26.

23. Aguilar-díaz H, Nava-castro KE, Escobedo G, Domínguez-ramírez L, García-varela M, Río-araiza VH, et al. A novel progesterone receptor membrane component ( PGRMC ) in the human and swine parasite Taenia solium: implications to the host-parasite relationship. 2019;(December 2018).

24. Oliveira G, Johnston DA. Mining the schistosome DNA sequence database [Internet]. Vol. 17, Trends in Parasitology. Elsevier Ltd; 2001 [cited 2020 Dec 14]. p. 501-3. Available from: https://pubmed.ncbi.nlm.nih.gov/11587966/

25. Hu W, Yan Q, Shen DK, Liu F, Zhu ZD, Song HD, et al. Evolutionary and biomedical implications of a Schistosoma japonicum complementary DNA resource. Nature Genetics [Internet]. 2003 Oct 1 [cited 2020 Dec 14];35(2):139-47. Available from: https://pubmed.ncbi.nlm.nih.gov/12973349/

26. Kapp N, Whyte P, Tang J, Jackson E, Brahmi D. A review of evidence for safe abortion care [Internet]. Vol. 88, Contraception. Contraception; 2013 [cited 2021 Mar 26]. p. 350-63. Available from: https://pubmed.ncbi.nlm.nih.gov/23261233/

27. Yu Y, Qi Y. Progress in Treatment and Prevention of Trichinellosis. Journal of Infectious Diseases \& Therapy [Internet]. 2015 Nov 30 [cited 2021 Mar 26];03(06). Available from: https://www.omicsonline.org/open-access/progress-in-treatment-and-prevention-of-trichinellosis2090-7214-1000251.php?aid=65895

28. Wang L, Cui J, Hu DD, Liu RD, Wang ZQ. Identification of early diagnostic antigens from major excretory-secretory proteins of Trichinella spiralis muscle larvae using immunoproteomics. Parasites and Vectors [Internet]. 2014 Jan 22 [cited 2020 Dec 10];7(1):40. Available from: /pmc/articles/PMC3905669/?report=abstract

29. Yang Y, Lacour SA, Lainé-Prade V, Versillé N, Grasset-Chevillot A, Feng S, et al. Trichinella spiralis newborn larvae: Characterization of a stage specific serine proteinase expression, NBL1, using monoclonal antibodies. Parasitology [Internet]. 2015 May 16 [cited 2020 Dec 16];142(6):783-90. Available from: https://www.cambridge.org/core/journals/parasitology/article/abs/trichinella-spiralisnewborn-larvae-characterization-of-a-stage-specific-serine-proteinase-expression-nbl1-usingmonoclonal-antibodies/49A2FD0B6E5494ACA37EF5A660C69DD9 
30. Virgo BB, Bellward GD. Serum Progesterone Levels in the Pregnant and Postpartum Laboratory Mouse. Endocrinology [Internet]. 1974 Nov 1 [cited 2020 Dec 9];95(5):1486-90. Available from: https://academic.oup.com/endo/article-lookup/doi/10.1210/endo-95-5-1486

31. González CG, García FD, Fernández SF, Patterson AM. Role of 17- $\beta$-estradiol and progesterone on glucose homeostasis: Effects of food restriction (50\%) in pregnant and non pregnant rats. Journal of Endocrinological Investigation [Internet]. $1997 \mathrm{Jul} 2$ [cited 2020 Dec 9];20(7):396-402. Available from: https://link.springer.com/article/10.1007/BF03347991

32. Anderson LL. Reproductive Biology of Pigs. Animal Industry Report: AS [Internet]. 2009 [cited 2020 Dec 9];655. Available from: https://doi.org/10.31274/ans_air-180814-838

33. M Ikoma D, Hulteen L, Holden J. Threshold progesterone level of $25 \mathrm{ng} / \mathrm{ml}$ to sustain pregnancy in first trimester in women with history of infertility or miscarriage. Clinical Obstetrics, Gynecology and Reproductive Medicine. 2018;4(1).

34. Liu TC, Pu HF, Wang PS. Unimpaired postreceptor regulation of luteinizing hormone secretion by gonadotropin-releasing hormone and estrogen in aged rat anterior pituitary cells. Endocrinology [Internet]. 1993 [cited 2021 Apr 7];132(3):1189-94. Available from:

https://pubmed.ncbi.nlm.nih.gov/8440179/

35. Liu RD, Wang ZQ, Wang L, Long SR, Ren HJ, Cui J. Analysis of differentially expressed genes of Trichinella spiralis larvae activated by bile and cultured with intestinal epithelial cells using real-time PCR. Parasitology Research [Internet]. 2013 Dec 12 [cited 2020 Dec 9];112(12):4113-20. Available from: http://link.springer.com/10.1007/s00436-013-3602-1

36. Cahill MA. Progesterone receptor membrane component 1: An integrative review [Internet]. Vol. 105, Journal of Steroid Biochemistry and Molecular Biology. J Steroid Biochem Mol Biol; 2007 [cited 2020 Dec 15]. p. 16-36. Available from: https://pubmed.ncbi.nlm.nih.gov/17583495/

37. Lösel RM, Besong D, Peluso JJ, Wehling M. Progesterone receptor membrane component 1-Many tasks for a versatile protein. Steroids [Internet]. 2008 Oct [cited 2020 Dec 15];73(9-10):929-34. Available from: https://pubmed.ncbi.nlm.nih.gov/18249431/

38. Falkenstein E, Meyer C, Eisen C, Scriba PC, Wehling M. Full-length cDNA sequence of a progesterone membrane-binding protein from porcine vascular smooth muscle cells. Biochemical and Biophysical Research Communications [Internet]. 1996 Dec 4 [cited 2020 Dec 15];229(1):86-9. Available from: https://pubmed.ncbi.nlm.nih.gov/8954087/

39. Peluso JJ. Multiplicity of progesterone's actions and receptors in the mammalian ovary [Internet]. Vol. 75, Biology of Reproduction. Biol Reprod; 2006 [cited 2020 Dec 15]. p. 2-8. Available from: https://pubmed.ncbi.nlm.nih.gov/16452458/

40. Krebs CJ, Jarvis ED, Chan J, Lydon JP, Ogawa S, Pfaff DW. A membrane-associated progesteronebinding protein, 25-Dx, is regulated by progesterone in brain regions involved in female reproductive behaviors. Proceedings of the National Academy of Sciences [Internet]. 2000 Nov 7 [cited 2020 Dec 15];97(23):12816-21. Available from: http://www.pnas.org/cgi/doi/10.1073/pnas.97.23.12816

41. Zhang L, Kanda Y, Roberts DJ, Ecker JL, Losel R, Wehling M, et al. Expression of progesterone receptor membrane component 1 and its partner serpine 1 mRNA binding protein in uterine and placental 
tissues of the mouse and human. Molecular and Cellular Endocrinology [Internet]. 2008 Jun 11 [cited 2020 Dec 15];287(1-2):81-9. Available from: https://pubmed.ncbi.nlm.nih.gov/18440126/

42. Peluso JJ, Liu X, Gawkowska A, Johnston-MacAnanny E. Progesterone Activates a Progesterone Receptor Membrane Component 1-Dependent Mechanism That Promotes Human Granulosa/Luteal Cell Survival But Not Progesterone Secretion. The Journal of Clinical Endocrinology \& Metabolism [Internet]. 2009 Jul 1 [cited 2020 Dec 15];94(7):2644-9. Available from: https://academic.oup.com/jcem/article/94/7/2644/2597510

43. Wu W, Shi SQ, Huang HJ, Balducci J, Garfield RE. Changes in PGRMC1, a potential progesterone receptor, in human myometrium during pregnancy and labour at term and preterm. Molecular Human Reproduction [Internet]. 2011 Apr [cited 2020 Dec 15];17(4):233-42. Available from: https://pubmed.ncbi.nlm.nih.gov/21131300/

44. Ace $\mathrm{Cl}$, Okulicz WC. Microarray profiling of progesterone-regulated endometrial genes during the rhesus monkey secretory phase. Reproductive Biology and Endocrinology [Internet]. 2004 Jul 7 [cited 2020 Dec 15];2(1):54. Available from: http://rbej.biomedcentral.com/articles/10.1186/1477-7827-2-54

45. Jiang H, Whitworth KM, Bivens NJ, Ries JE, Woods RJ, Forrester LJ, et al. Large-scale generation and analysis of expressed sequence tags from porcine ovary. Biology of Reproduction [Internet]. 2004 Dec [cited 2020 Dec 15];71(6):1991-2002. Available from: https://pubmed.ncbi.nlm.nih.gov/15306552/

46. Hughes AL, Powell DW, Bard M, Eckstein J, Barbuch R, Link AJ, et al. Dap1/PGRMC1 Binds and Regulates Cytochrome P450 Enzymes. Cell Metabolism [Internet]. 2007 Feb 7 [cited 2020 Dec 15];5(2):143-9. Available from: https://pubmed.ncbi.nIm.nih.gov/17276356/

47. Luciano AM, Corbani D, Lodde V, Tessaro I, Franciosi F, Peluso JJ, et al. Expression of progesterone receptor membrane component- 1 in bovine reproductive system during estrous cycle. European journal of histochemistry: EJH [Internet]. 2011 [cited 2020 Dec 15];55(3). Available from: https://pubmed.ncbi.nlm.nih.gov/22073374/

48. Peluso JJ, Liu X, Gawkowska A, Lodde V, Wu CA. Progesterone inhibits apoptosis in part by PGRMC1regulated gene expression. Molecular and Cellular Endocrinology [Internet]. 2010 May [cited 2020 Dec 15];320(1-2):153-61. Available from: https://pubmed.ncbi.nlm.nih.gov/20144686/

49. Wendler A, Wehling M. PGRMC2, a yet uncharacterized protein with potential as tumor suppressor, migration inhibitor, and regulator of cytochrome P450 enzyme activity. In: Steroids [Internet]. Steroids; 2013 [cited 2020 Dec 15]. p. 555-8. Available from: https://pubmed.ncbi.nlm.nih.gov/23276631/

50. Keator CS, Mah K, Slayden OD. Alterations in progesterone receptor membrane component 2 (PGRMC2) in the endometrium of macaques afflicted with advanced endometriosis. Molecular Human Reproduction [Internet]. 2012 Jun [cited 2020 Sep 2];18(6):308-19. Available from: /pmc/articles/PMC3358041/?report=abstract

51. Georgiou HM, Di Quinzio MKW, Permezel M, Brennecke SP. Predicting Preterm Labour: Current Status and Future Prospects [Internet]. Vol. 2015, Disease Markers. Hindawi Limited; 2015 [cited 2020 Dec 15]. Available from: /pmc/articles/PMC4486247/?report=abstract

52. Causey MW, Huston LJ, Harold DM, Charaba CJ, Ippolito DL, Hoffer ZS, et al. Transcriptional analysis of novel hormone receptors PGRMC1 and PGRMC2 as potential biomarkers of breast adenocarcinoma 
staging. Journal of Surgical Research [Internet]. 2011 Dec [cited 2020 Dec 15];171(2):615-22. Available from: https://pubmed.ncbi.nlm.nih.gov/20655063/

53. Slonina D, Kowalik MK, Kotwica J. Expression of progesterone receptor membrane component 1 , serpine mRNA binding protein 1 and nuclear progesterone receptor isoforms $A$ and $B$ in the bovine myometrium during the estrous cycle and early pregnancy. Journal of Reproduction and Development [Internet]. 2012 [cited 2020 Dec 15];58(3):288-94. Available from:

https://pubmed.ncbi.nlm.nih.gov/22277931/

54. Saint-Dizier M, Sandra O, Ployart S, Chebrout M, Constant F. Expression of nuclear progesterone receptor and progesterone receptor membrane components 1 and 2 in the oviduct of cyclic and pregnant cows during the post-ovulation period. Reproductive Biology and Endocrinology. 2012;10:112.

55. Miller L, Hunt JS. Sex steroid hormones and macrophage function [Internet]. Vol. 59, Life Sciences. Elsevier Inc.; 1996 [cited 2020 Dec 16]. p. 1-14. Available from: https://pubmed.ncbi.nlm.nih.gov/8684265/

56. Piccinni MP, Scaletti C, Maggi E, Romagnani S. Role of hormone-controlled Th1- and Th2-type cytokines in successful pregnancy. Journal of Neuroimmunology [Internet]. 2000 Sep 1 [cited 2020 Dec 16];109(1):30-3. Available from: https://pubmed.ncbi.nlm.nih.gov/10969178/

57. Roberts CW, Walker W, Alexander J. Sex-associated hormones and immunity to protozoan parasites [Internet]. Vol. 14, Clinical Microbiology Reviews. Clin Microbiol Rev; 2001 [cited 2020 Dec 16]. p. 47688. Available from: https://pubmed.ncbi.nlm.nih.gov/11432809/

58. Veenstra van Nieuwenhoven AL, Bouman A, Moes H, Heineman MJ, De Leij LFMH, Santema J, et al. Cytokine production in natural killer cells and lymphocytes in pregnant women compared with women in the follicular phase of the ovarian cycle. Fertility and Sterility [Internet]. 2002 [cited 2020 Dec 16];77(5):1032-7. Available from: https://pubmed.ncbi.nlm.nih.gov/12009363/

59. Nuñez GG, Gentile T, Costantino SN, Sarchi MI, Venturiello SM. In vitro and in vivo effects of progesterone on Trichinella spiralis newborn larvae. Parasitology [Internet]. 2005 Aug [cited 2020 Dec 13];131(2):255-9. Available from: https://pubmed.ncbi.nlm.nih.gov/16145942/

60. Beagley KW, Gockel CM. Regulation of innate and adaptive immunity by the female sex hormones oestradiol and progesterone [Internet]. Vol. 38, FEMS Immunology and Medical Microbiology. Elsevier; 2003 [cited 2020 Dec 16]. p. 13-22. Available from: https://pubmed.ncbi.nlm.nih.gov/12900050/

61. Charniga L, Stewart GL, Kramar GW, Stanfield JA. The effects of host sex on enteric response to infection with Trichinella spiralis. Journal of Parasitology. 1981;67(6):917-22.

62. Reddington JJ, Stewart GL, Kramar GW, Kramar MA. The effects of host sex and hormones on Trichinella spiralis in the mouse. Journal of Parasitology. 1981;67(4):548-55.

63. Figallová V, Prokopic J. The effects of host sex and sex hormones on Trichinella spiralis Owen, 1835 and T. pseudospiralis Garkavi, 1972 in the mouse. Folia parasitologica [Internet]. 1988 Jan 1 [cited 2020 Dec 16];35(1):59-66. Available from: https://europepmc.org/article/med/2971003 
64. Thabet HS, Thabet SS, Ali NM, Ahmed NS. Effects of ovariectomy and thyroidectomy on course and outcome of Trichinella spiralis infection in rat. Journal of the Egyptian Society of Parasitology [Internet]. 2008 Apr 1 [cited 2020 Dec 16];38(1):29-46. Available from: https://europepmc.org/article/med/19143118

65. Gagliardo LF, McVay CS, Appleton JA. Molting, ecdysis, and reproduction of Trichinella spiralis are supported in vitro by intestinal epithelial cells. Infection and Immunity [Internet]. 2002 [cited 2021 Mar 26];70(4):1853-9. Available from: https://pubmed.ncbi.nlm.nih.gov/11895947/

\section{Figures}

A

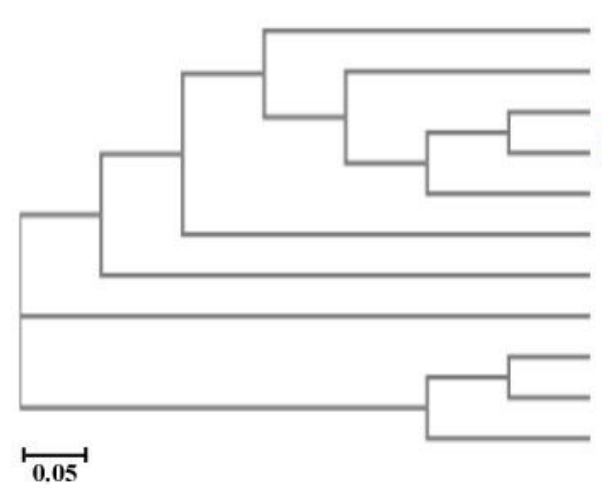

OUC48514.10.00416

KRY42018.10.01573

KRY77118.10.05644

Trichinella -0.01264

XP_003375934.10.00927

KRZ̈59629.1-0.0081

KRY20999.10.0119

KRX51206.10.01276

KRY59148.10.02168

KRX67724.1-0.02168

KRX24467.1-0.00748
B

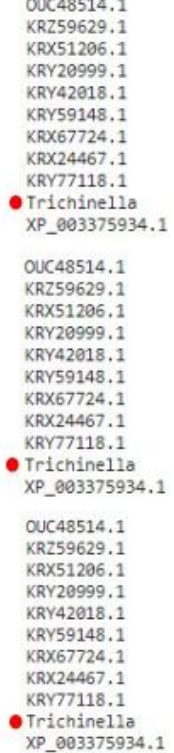

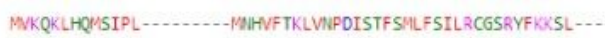

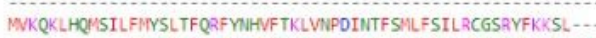
..............WYSLTFQRFYDHVFTKLVWPDISTFSMLFSILRCGSGYFKKSLFLIANKRKLHHVSIPLIWINFTKLLVUPDISTFSMLFSILRCGSRYFKXSLFLMAENERULNSIFFL

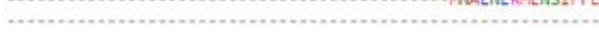

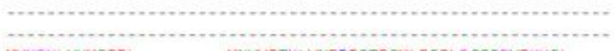
MVKRKLHHISIPL .........-WWHWFTKLVWPDISTFSMLFSILRCGSRYFKKSL .... SVLESAGMFULIFAGILAVI-MLLAAFDFMRFRIKWTSKDGRQLSGDCPPPM LESAGMILLIFAGILAVI-MLL LAAFDFNRFRIKUTSKDGROL SGDCPPPM SVLESAGIFILIFAGILAVI -MLLLAFDFNRFRIKWTSKDGRQL SGDCPPPM - IDSRSSVLESAGIFILIFAGILAVI-MLLAAFDFNRFRIKWTSKDGROLSGDCPPP -IIDLRSSVLESAGMFILIFAGILAVI -MLLAAFDFMRFRIKMTSKDGRQLSGDCPPP EXRIALFTSVLESAGVILLIFAGI LAVI -MLLAAFDFNRFRIKUTSKDGROLSGDCPPP: LESAGMFILIFAGILAVI-MLLAAFDFMRFRIKWTSKDGROLSGDCPPPM LESAGIFLLIFAGILAVT-MLLAAFDFNRFRTKLTSKDGROLSGDCPPP - SVLESAGAFILIFAGILAVI - MLLAAFDFNRFRIKUTSKDGRQLSGDCPPPM FSTEMVHI KDTYDDLADLTLSEINSLRENATO …...FAOYYPCVGXLLSSSDQAOFRTD FSTEMVHIKDTYDDLADLTLSEINSLRENATO-..... FAOMYPCVGKLLSSSDOADFRTD FSTEMVHIKDTYDDLADLTLSEINSL RENAMQ-.....FAQMYPCVGKLLLSSDQADFRTD FSTEMVHIKDTYDDLADLTLSEINSLRENAMO-.....-FAQYYYPCVGKLLLSSSDOADFRTD FSTEMVHI KDTYDDLADLTLSEINSLRENAANO-....-FAOAYPCVGKLLSSSDOADFRTD FSTEMVHI KDTYDDLADLTLSEINSL REWAMO-...-FAOMYPCVG LLSSSDQADFRTD FSTEMVHI KDTYDDLADLTLSEINSLREWAMO-......FAQMYPCVGKLLSSSDOADFRTD FSTEMVHIKDTYDDLADLTLSEINSLREWAMQ-...-FAQMYPCVGKLLSSSDQADFRTD FSTEMVHI KDSYDDLADLTLSEINSLRENANAHEL RSYFKEMYPCVGKLLSSSDQADFRTD FSTEMVHIKDTYDDLADLTLSEINSLRENAMHELKSCLKEMYPCVGKLLSSSDOADFRTD FSTEMVHIKDTYDDLADLTLSEINSLREWANHELKSCLKEMYPCVGKLLSSSDQADFRTD

\section{Figure 1}

Phylogenetic tree and multiple sequence alignment. (A) A phylogenetic tree of Ts-MAPRC2 and homologs with other species. (B) Multiple Sequence Alignment of Ts-MAPRC2 by Clustal Omega with other trichinella species. Different colors show the amino acid identity, and gaps represent the sequence with other trichinella species, respectively. 


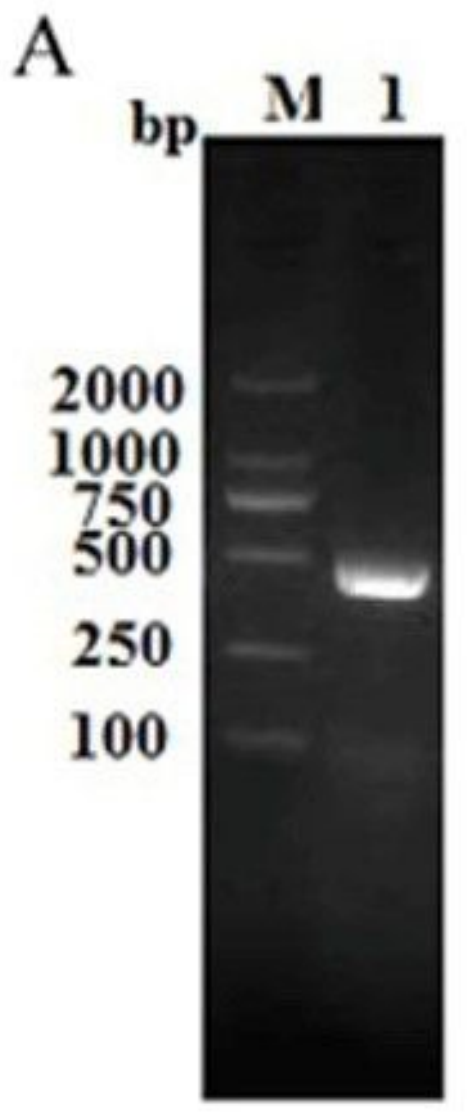

B

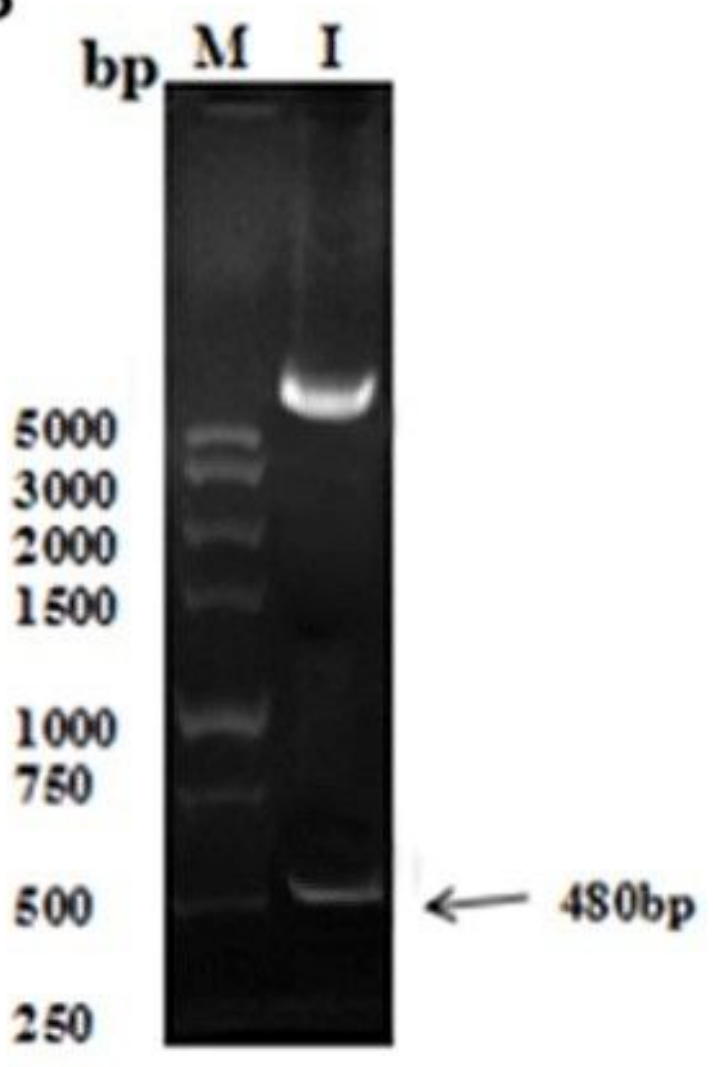

Figure 2

Cloning of Ts-MAPRC2 gene and identification of recombinant plasmid (pET-32a (+) Ts-MAPRC2. Lane M represents DNA marker (A) Lane 1; Ts-MAPRC2 gene amplified by PCR (B) Lane 1; Digested recombinant plasmid $\{($ pET-32a $(+)\}$ Ts-MAPRC2 with EcoR1 and Hind III.
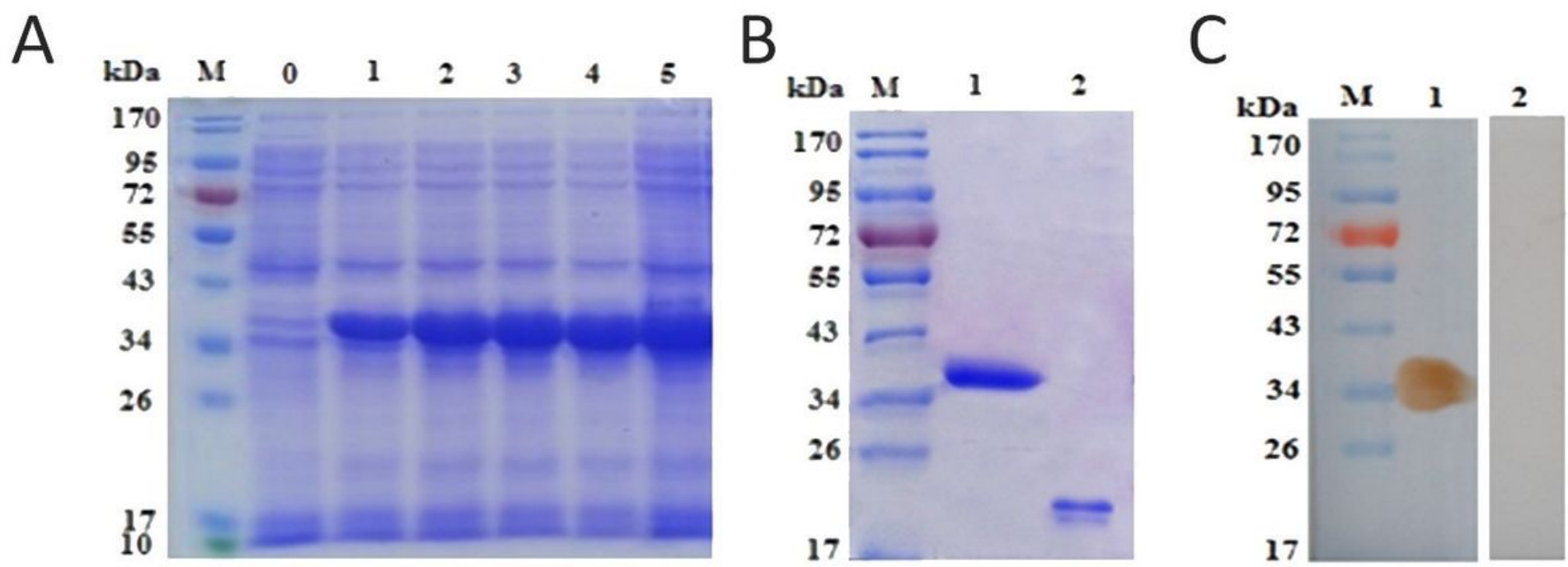

Figure 3 
Expression and purification of rTs-MAPRC2. Lane M: Standard molecular weight of protein marker Lane 0: Recombinant expression vector prior IPTG (isopropyl-ß-d-thiogalactopyranoside) induction. (A) Lane 1-5: Expression of rTs-MAPRC2 protein after IPTG induction at different time points. (B) Lane 1: Purified expression of the rTs-MAPRC2 protein. Lane 2: Expression of pET-32a protein resolved on SDS-PAGE. (C) M: Standard marker molecular weight. Lane 1: Purified rTs-MAPRC2 protein was shifted to the membrane and probed with SD rat serum immunized by rTs-MAPRC2 protein. Lane 2: Membrane probed by normal rat serum as control.

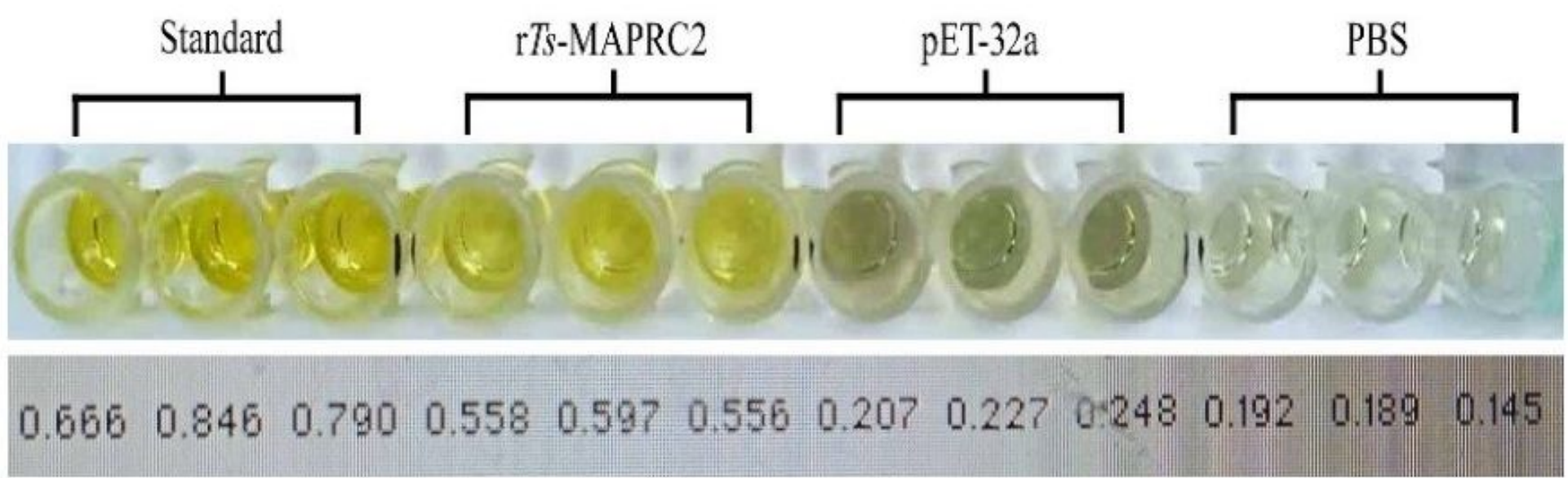

\section{Figure 4}

The binding ability of rTs-MAPRC2 protein compared to pET-32a and PBS as control by using a (PROG-Ab) Sandwich ELISA kit (OD450). The data were shown in three independent trials $(n=3)$. 


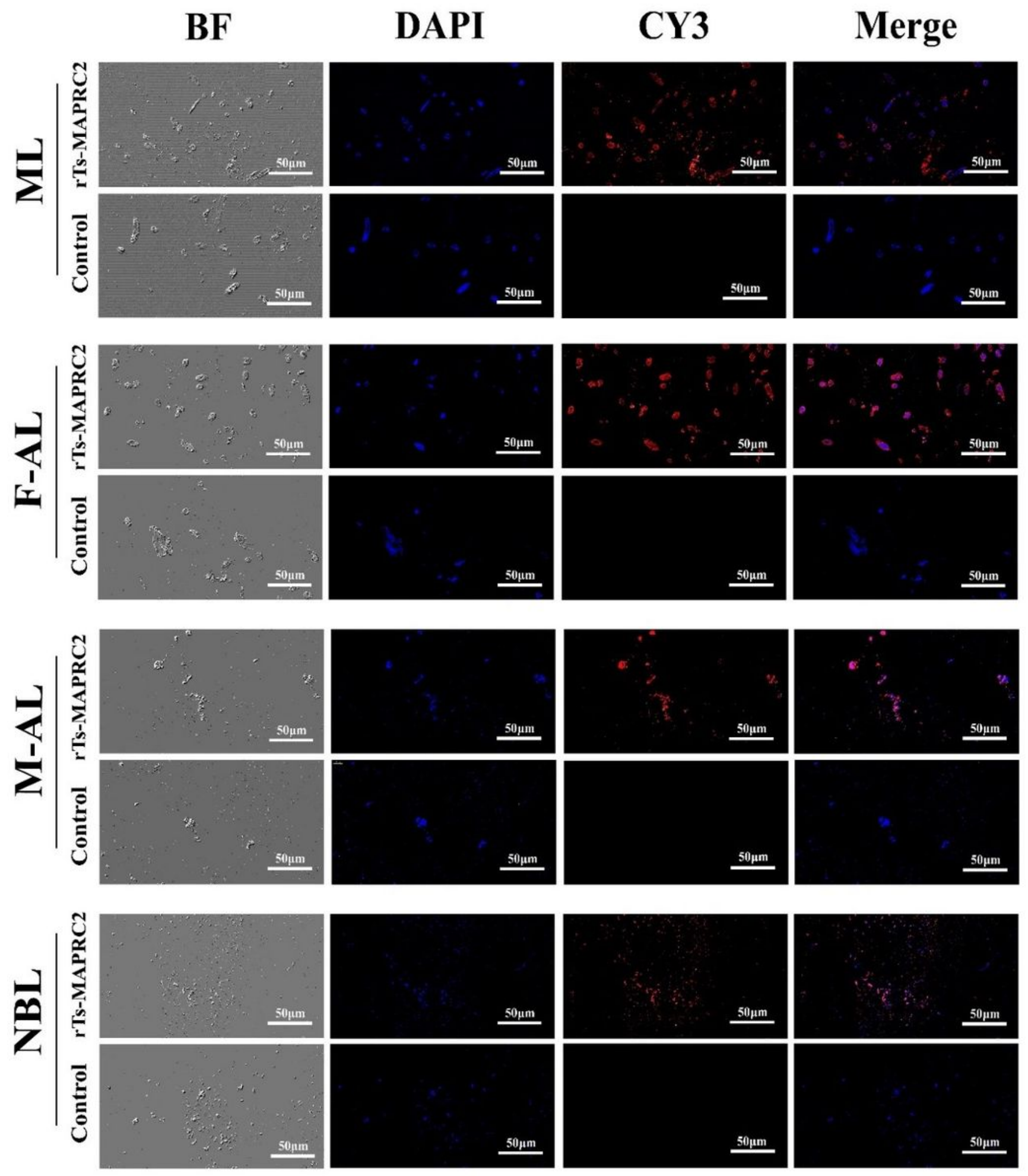

Figure 5

Immunolocalization of Ts-MAPRC2 at different developmental stages of T. spiralis. Cross-section of Intact worms of all stages (F-AL, M-AL, ML, and NBL) were studied using IFA with anti-rTs-MAPR sera followed by BF (Bright field), DAPI, staining with Cy3-conjugated secondary antibody, and Merge. ML and F-AL stages showed high Ts-MAPR gene localization as compared to M-AL and NBL stages. Moreover, F-AL showed 
high immunolocalization compared to M-AL. No fluorescence was observed in control of all the worm's developmental stages with a scale bar of $50 \mu \mathrm{m}$.
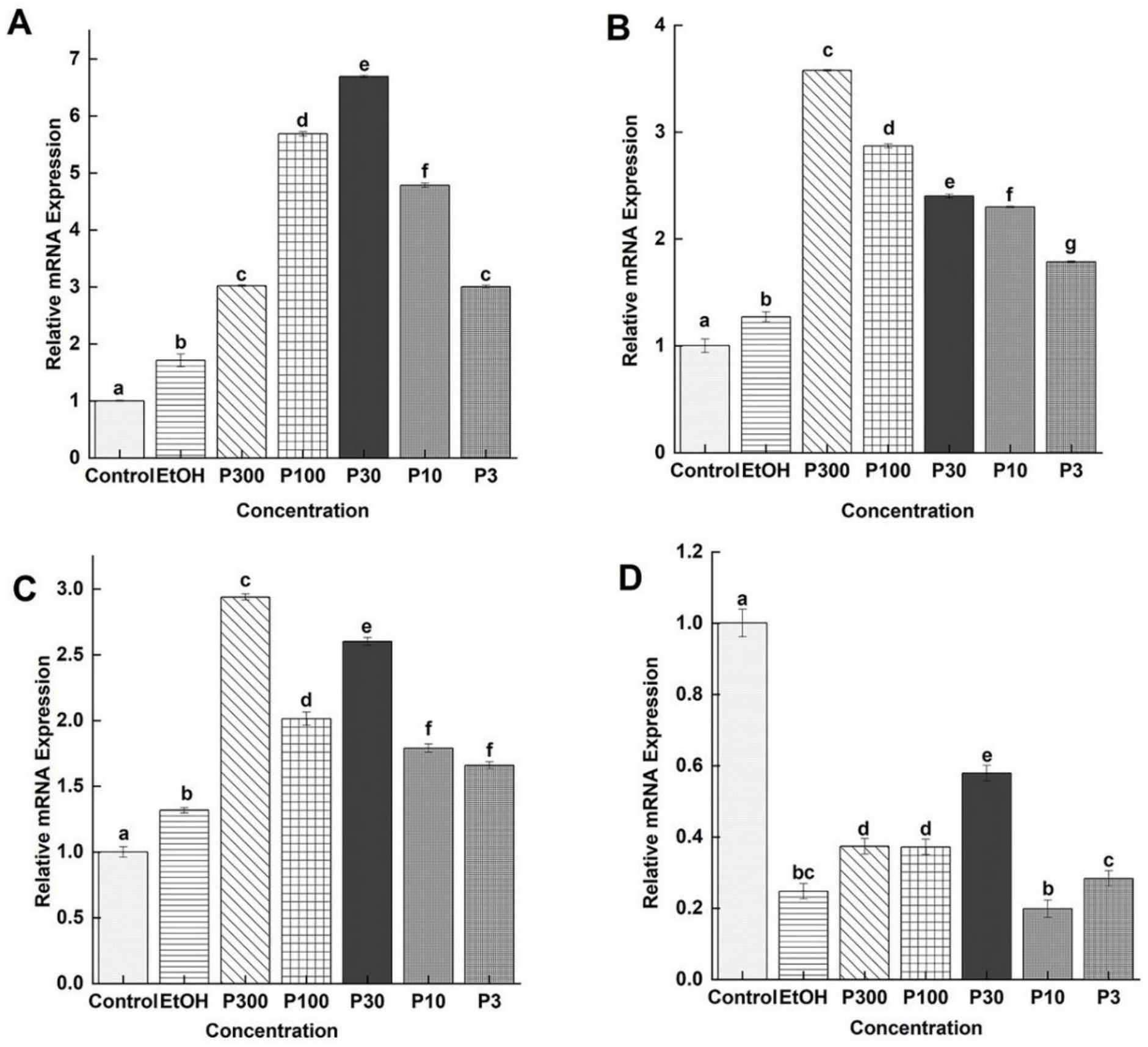

Figure 6

Relative mRNA levels of Ts-MAPRC2 at various developmental phases of T. spiralis. The Comparison between the different concentration of P4 (P300 ng/mL, P100 ng/mL, P30 ng/mL, P10 ng/mL, P3 ng/mL) with control (only RPMI) and control vehicle ethanol (EtOH-RPMI) among the same developmental stages (A) F-AL (B) M-AL (C) ML (D) NBL of Trichinella spiralis. Statistical data were presented as mean \pm SD $(n=3) . P \leq 0.05, P \leq 0.01$ were considered significant. The same letters mean non-significant and the different letters mean significant. 


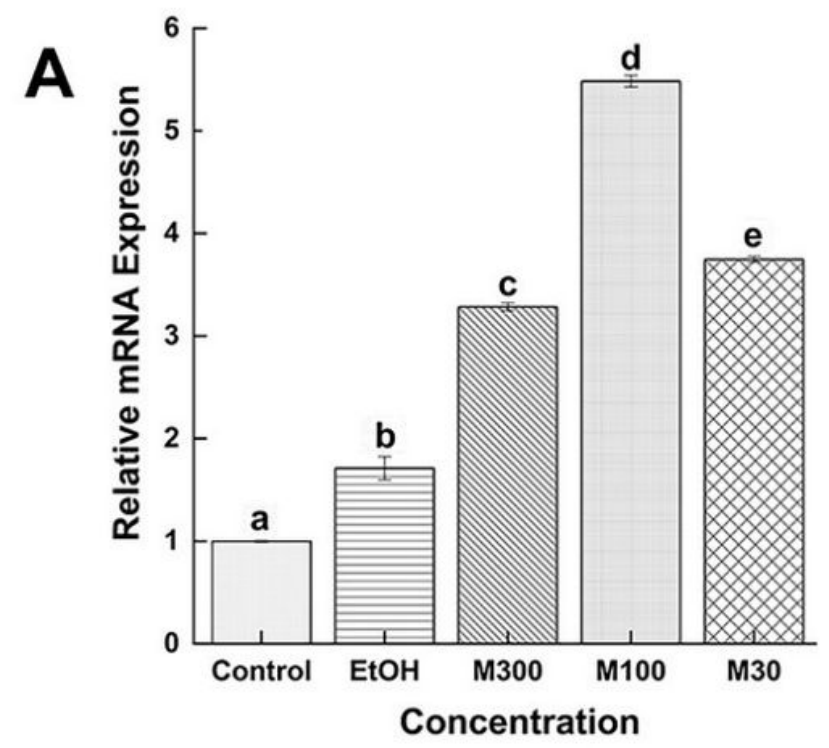

B
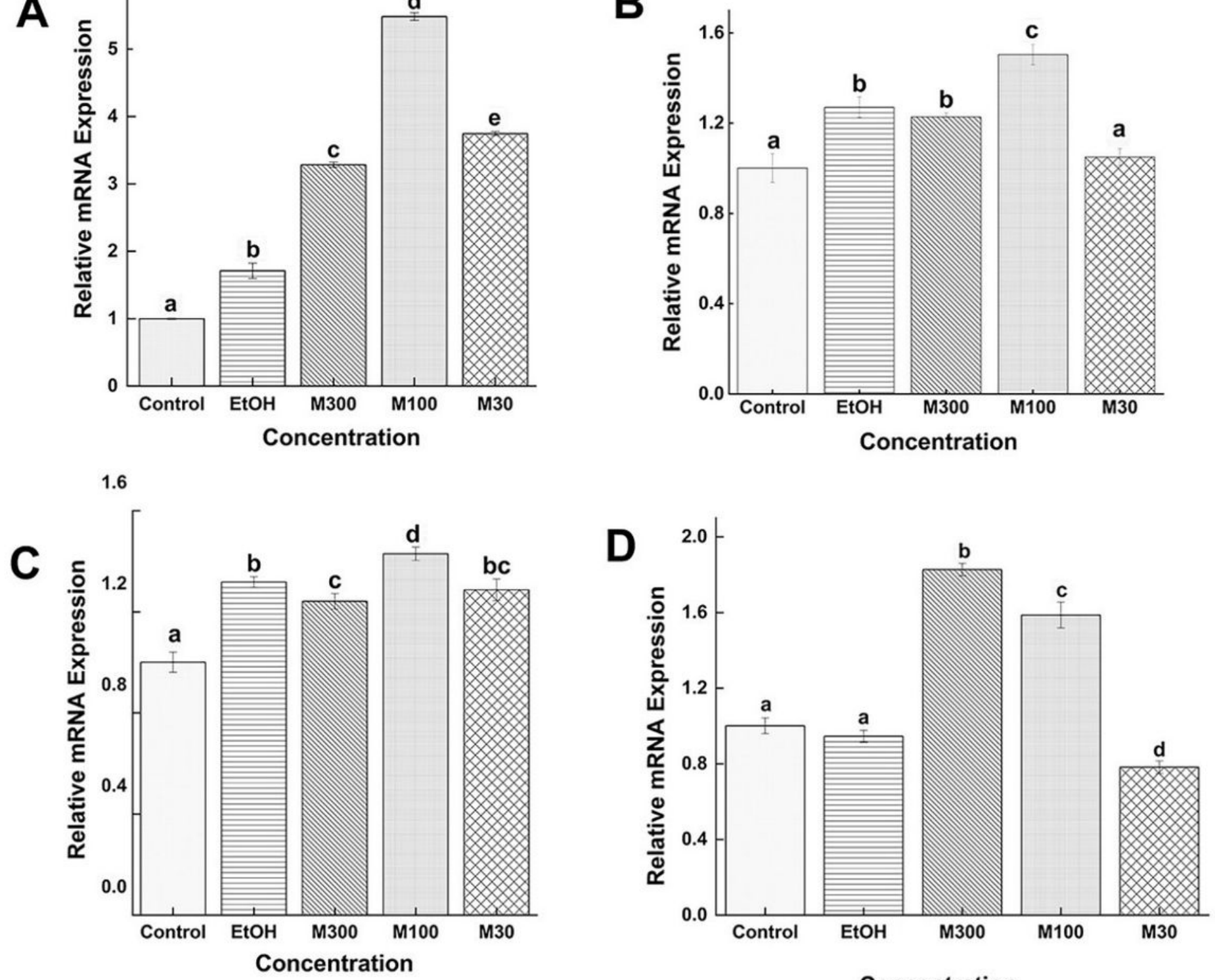

Concentration

Figure 7

Relative mRNA levels of Ts-MAPRC2 at various developmental phases of T. spiralis. The Comparison between the different concentration of mifepristone (M300 ng/mL, M100 ng/mL, M30 ng/mL) with control (only RPMI) and control vehicle ethanol (EtOH-RPMI) among the same developmental stages (A) F-AL (B) M-AL (C) ML (D) NBL of Trichinella spiralis. Statistical data were presented as mean $\pm S D(n=3) . P \leq 0.05$ were considered significant. The same letters mean non-significant and the different letters mean significant. 

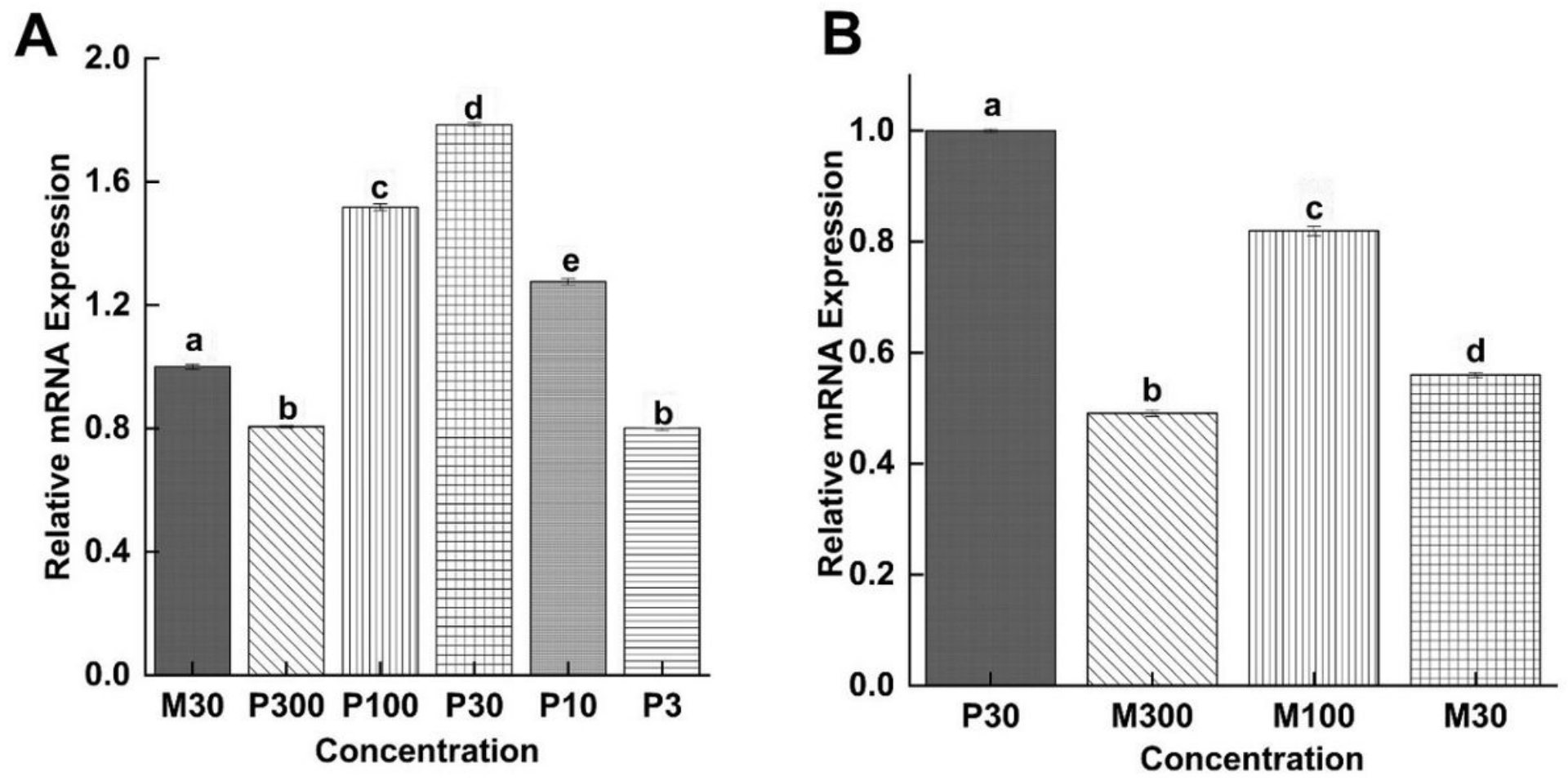

Figure 8

Relative mRNA expression of Ts-MAPRC2 at F-AL (Female adult worm) phase of T. spiralis. (A) Comparison between the different concentration of P4 (P300 ng/mL, P100 ng/mL, P30 ng/mL, P10 $\mathrm{ng} / \mathrm{mL}$, P3 $\mathrm{ng} / \mathrm{mL}$ ) with $\mathrm{M} 30 \mathrm{ng} / \mathrm{mL}$ as control. (B) Comparison between the different concentration of mifepristone (M300 ng/mL, M100 ng/mL, M30 ng/mL) with P30 ng/mL as control. Statistical data were presented as mean $\pm S D(n=3)$. $P \leq 0.05$ were considered significant. The same latter's means nonsignificant and different letters mean significant. 
A

F-AL

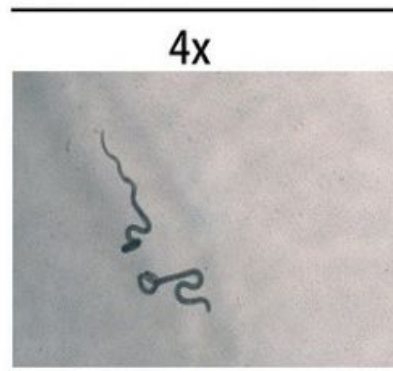

Control

$\mathrm{EtOH}$

M100
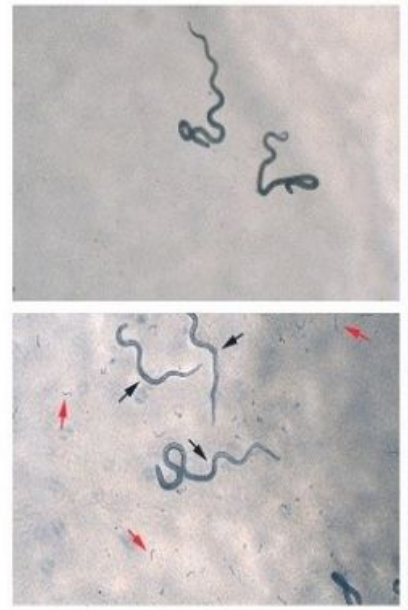

P30
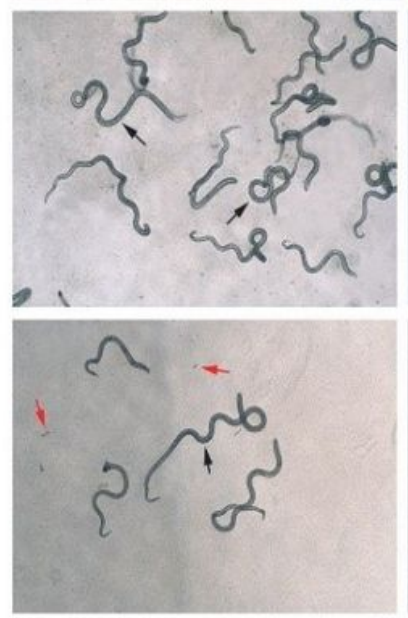

MAPRC2-

$\mathrm{Ab}$
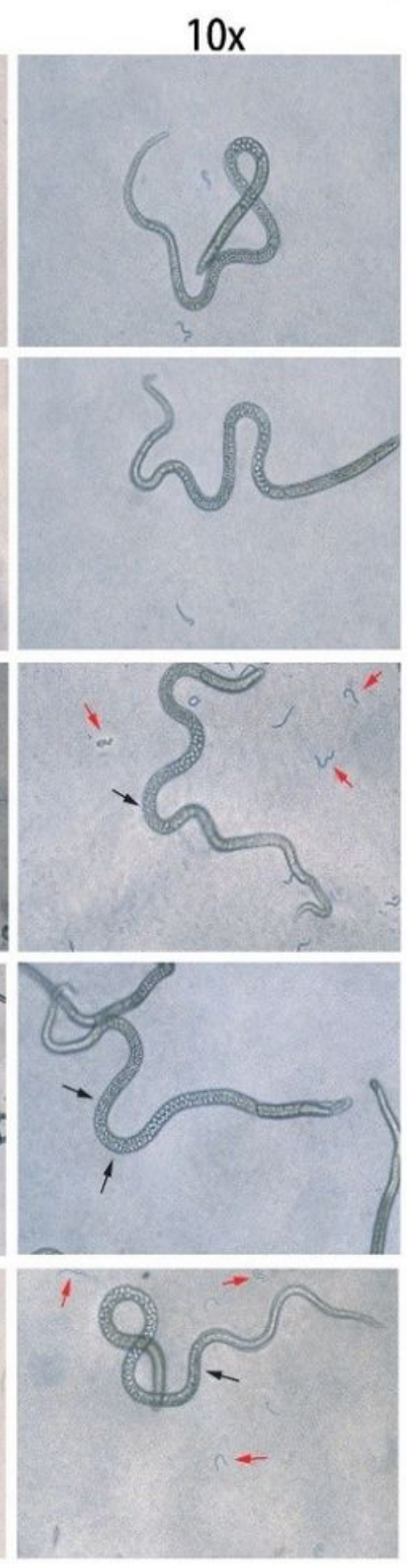

B
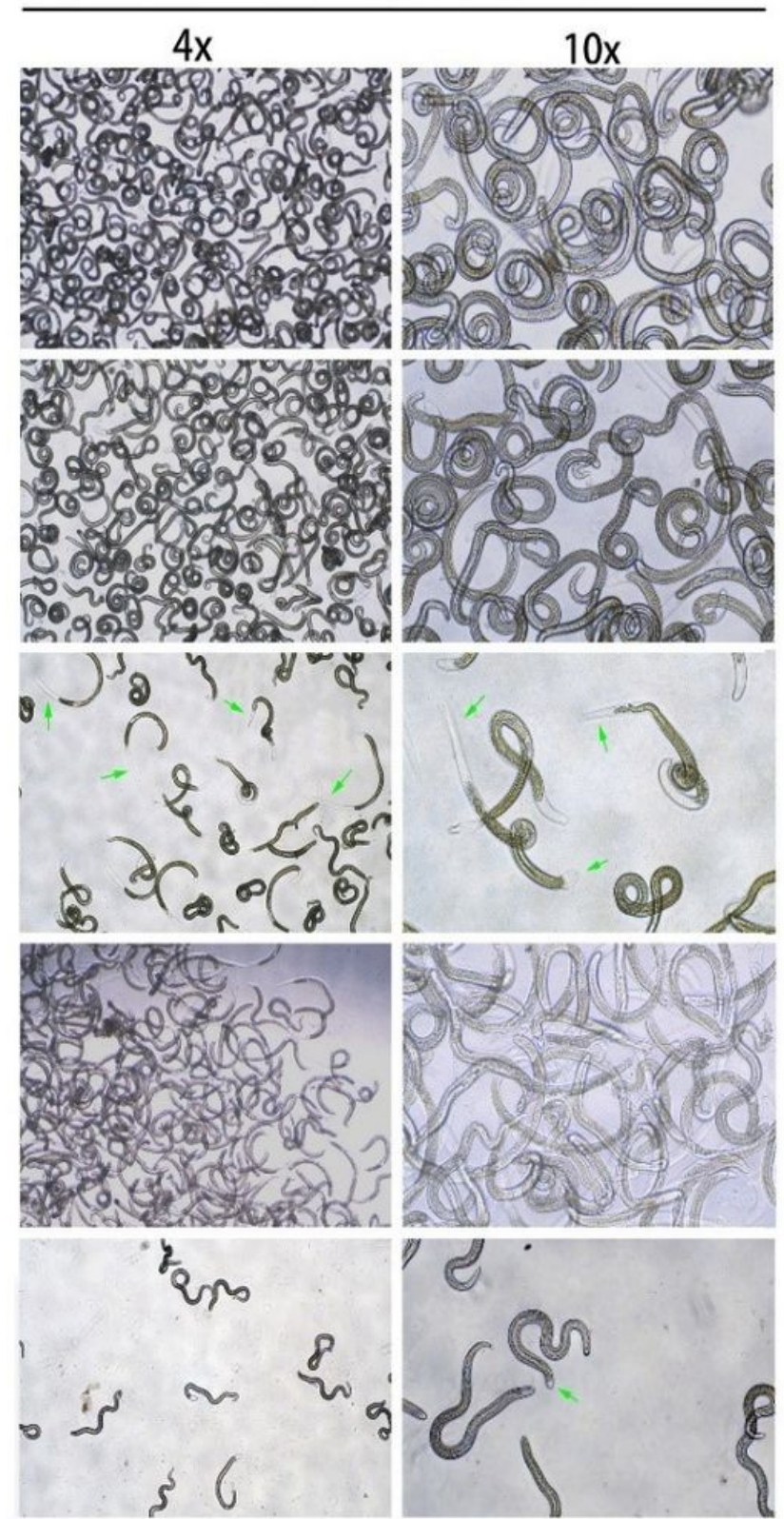

\section{Figure 9}

The in-Vitro phenotypic effect of P30 $(\mathrm{ng} / \mathrm{mL}), \mathrm{M} 100(\mathrm{ng} / \mathrm{mL})$, and $\mathrm{rTs}-\mathrm{MAPRC}-\mathrm{Ab}$ on F-AL (female adult worm) and $\mathrm{ML}$ (muscle larvae) stages were observed. (A) Compared the phenotypic appearance of pregnant female adult worm (F-AL) among P30 $(\mathrm{ng} / \mathrm{mL}), \mathrm{M} 100(\mathrm{ng} / \mathrm{mL})$, and rTs-MAPRC2-Ab with both controls (only RPMI and EtOH-RPMI). Black arrows presented a female pregnancy site while red arrows present new borne larvae (NBL) at objective 4x and 10x. (B) Compared the phenotype appearance of muscle larvae $(\mathrm{ML})$ among P30 $(\mathrm{ng} / \mathrm{mL}), \mathrm{M} 100(\mathrm{ng} / \mathrm{mL})$, and rTs-MAPRC2-Ab with both controls (only RPMI and EtOH-RPMI) to observed ecdysis (molting process is shown by green arrow) and motility at objective $4 x$ and $10 x$. 

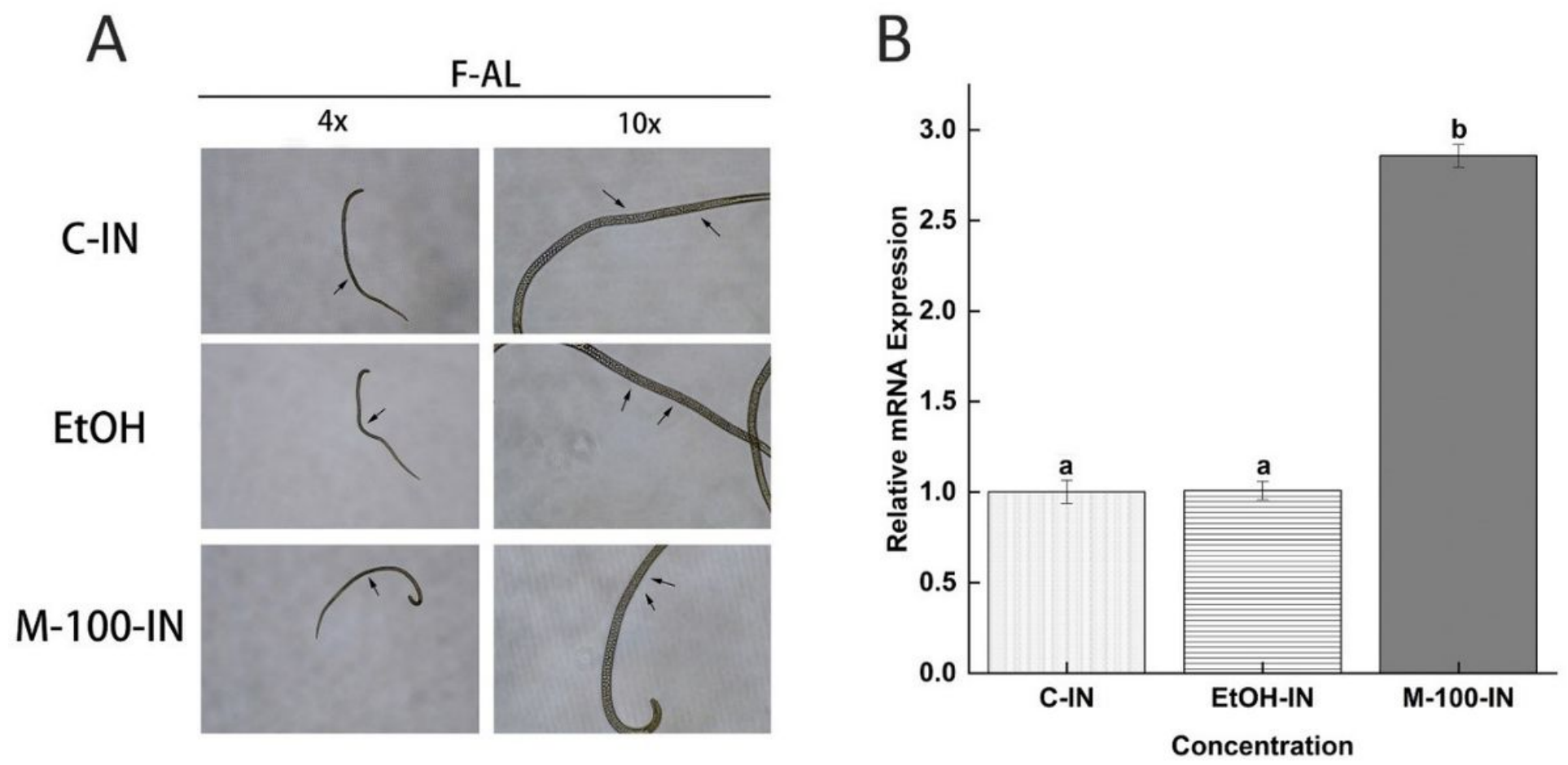

Figure 10

The in-vivo phenotypic effect and relative mRNA expression of mifepristone (M100 ng/mL) on F-AL (female adult worm) were observed. (A) Compared the phenotypic appearance of early pregnancy stage of female adult worm (F-AL) among $\mathrm{M} 100(\mathrm{ng} / \mathrm{mL}$ ) with control and adjuvants EtOH (Olive oil-ethanol) at objective 4x and 10x. (B) Relative mRNA expression of Ts-MAPRC2 at F-AL (Female adult worm) phase of T. spiralis by in-vivo study. Here a comparison between $\mathrm{M} 100(\mathrm{ng} / \mathrm{mL})$ with a simple control group and adjuvants EtOH (Olive oil-ethanol) group. Statistical data were presented as mean $\pm S D(n=3)$. $P \leq 0.05$ were considered significant. The same letters mean non-significant and different letters mean significant.

\section{Supplementary Files}

This is a list of supplementary files associated with this preprint. Click to download.

- SupplementaryFileS1.docx 